\title{
PROTEIN KINASE R PLAYS A PIVOTAL ROLE IN ONCOSTATIN M AND INTERLEUKIN-1 SIGNALLING IN BOVINE ARTICULAR CARTILAGE CHONDROCYTES
}

\author{
S.J. Gilbert*, E.J. Blain, A. Al-Sabah, Y. Zhang, V.C. Duance and D.J. Mason
}

Arthritis Research UK Biomechanics and Bioengineering Centre, Pathophysiology and Repair Division, School of Biosciences, Cardiff University, Cardiff, CF10 3AX, UK

Abstract

This study investigated whether treatment of articular cartilage chondrocytes with a combination of oncostatin $\mathrm{M}$ (OSM) and interleukin-1 (IL-1) could induce a degradative phenotype that was mediated through the protein kinase $\mathrm{R}$ (PKR) signalling pathway. High-density monolayer cultures of full depth, bovine chondrocytes were treated with a combination of OSM and IL-1 (OSM+IL-1) for 7 days. To inhibit the activation of PKR, a pharmacological inhibitor of PKR was added to duplicate cultures. Pro- and active matrix metalloproteinase-9 (MMP9) and MMP9 mRNA were significantly upregulated by OSM+IL-1 through a PKR dependent mechanism. ADAMTS4 and ADAMTS5 mRNA were also upregulated by OSM+IL-1. The upregulation of ADAMTS4 and ADAMTS5 were, in part, mediated through PKR. OSM+IL-1 resulted in a loss of type II collagen, which could not be rescued by PKR inhibition. OSM+IL-1 reduced the expression of COL2A1 (type II collagen), COL9A1 (type IX collagen), COL11A1 (type XI collagen), and $A C A N$ (aggrecan) mRNAs. Expression of type II and $\mathrm{XI}$ collagen and aggrecan was reduced further when PKR was inhibited. OSM+IL-1 resulted in an 11-fold increase in $T N F \propto$ mRNA which was, in part, mediated through the PKR pathway. This study demonstrates, for the first time, that a number of catabolic and pro-inflammatory effects known to be important in human arthritis and induced by OSM and IL-1, are mediated by the PKR signalling pathway.

Keywords: Articular cartilage, chondrocytes, protein kinase $\mathrm{R}$, oncostatin $\mathrm{M}$, interleukin-1, matrix metalloproteinase, aggrecanase, tumour necrosis factor alpha, type II collagen.

*Address for correspondence:

S.J. Gilbert,

School of Biosciences, Cardiff University

Museum Avenue, Cardiff, CF10 3AX

Wales, UK

Telephone Number: +44 (0) 2920874287

FAX: +44 (0) 2920874594

E-mail: gilbertsj1@Cardiff.ac.uk
Abbreviations

$\mathrm{MMP}=$ matrix metalloproteinase; $\operatorname{ADAMTS}=\mathrm{a}$ disintegrin and metalloproteinase with thrombospondin motif; OSM = oncostatin M; IL-1 = interleukin-1; PKR $=$ protein kinase $\mathrm{R} ; \mathrm{PKRi}=\mathrm{PKR}$ inhibitor; PKRi neg $=$ PKR inactive inhibitor; TNF $\alpha=$ tumour necrosis factor $\alpha$; eIF $2 \alpha=$ eukaryotic initiation factor 2 alpha; $\mathrm{I} \kappa \mathrm{B} \alpha=$ the inhibitor of kappa B; NFкB = nuclear factor kappa B; DMEM = Dulbecco's Modified Eagle's Medium; ITS = insulin-transferrin-sodium selenite $; \mathrm{LDH}=$ lactate dehydrogenase; SDS = sodium dodecyl sulphate; TBST $=$ tris buffered saline with tween 20; GLM-ANOVA $=$ general linear model analysis of variance; $\Delta \Delta \mathrm{C}_{\mathrm{T}}=$ delta delta threshold cycle.

\section{Introduction}

Cartilage degradation occurs as a result of an imbalance between extracellular matrix proteinases and their inhibitors, in particular matrix metalloproteinases (MMPs) and aggrecanases (ADAMTSs; a disintegrin and metalloproteinase with thrombospondin motif) and the tissue inhibitors of metalloproteinases. These enzymes are induced in arthritic disease by a number of proinflammatory cytokines such as tumour necrosis factor $\alpha(\mathrm{TNF} \alpha)$, interleukin-1 (IL-1), and oncostatin M (OSM). OSM is a member of the interleukin-6 superfamily of cytokines and has been implicated in inflammatory joint disease (Cawston et al., 1998; Langdon et al., 2000). Several studies have shown that OSM signals synergistically with IL-1 in cartilage, inducing collagen (Cawston et al., 1995) and aggrecan (Cawston et al., 1998; Durigova et al., 2011) degradation via up-regulation of MMPs (Blain et al., 2010; Cawston et al., 1998; Hui et al., 2003; Milner et al., 2006) and ADAMTSs (Hui et al., 2005; El Mabrouk et al., 2007; Durigova et al., 2008; Durigova et al., 2011), respectively. In particular, OSM potently induces MMP13 in human and bovine articular cartilage (Fearon et al., 2006; El Mabrouk et al., 2007; Blain et al., 2010) upregulation of which plays a crucial role in the pathology of degenerative joint disease ((Little et al., 2009) and reviewed in (Takaishi et al., 2008; van den Berg, 2011)).

Previously, we have shown that the TNF $\alpha$ induced upregulation of MMP9 expression and activation in articular cartilage occurs through a novel mechanism involving the interferon-induced, double-stranded RNAactivated protein kinase, PKR (Gilbert et al., 2004). PKR is expressed at constitutively low levels in a number of cell types, including chondrocytes, and mediates a stress-induced signalling pathway that is activated in 
early osteoarthritis in vivo (reviewed in (Gilbert et al., 2006b)). PKR expression and activation is upregulated by proinflammatory signals including TNF $\alpha$ (Gilbert et al., 2002) and IL-1 (Tam et al., 2007) resulting in proteoglycan degradation (Gilbert et al., 2004; Tam et al., 2007), phosphorylation of the eukaryotic initiation factor 2 alpha (eIF2 $\alpha$ ) (Gilbert et al., 2002) and down-regulation of protein synthesis (reviewed in Gilbert et al., 2006b). This inhibition of protein synthesis has been shown to be important in controlling cell growth (reviewed in Clemens and Elia, 1997) and in increasing the cells susceptibility to apoptosis (Lee and Esteban, 1994). Interestingly, work by Osman et al. has uncovered a role for PKR in the regulation of TNFa (Osman et al., 1999). A cis-acting element within the 3'UTR of the $T N F \alpha$ mRNA binds to and activates PKR in response to external stimuli, which in turn increases $T N F \alpha$ pre-mRNA splicing efficiency up to 20-fold when the amount of PKR increases (Osman et al., 1999). Therefore, since the cis-acting element is capable of acting as a sensor, responding to the levels of PKR in the cell, a positive feedback loop is established for TNF $\alpha$ production within the cell (reviewed in (Kaempfer, 2003; Gilbert et al., 2006b)). Thus, splicing of TNF $\alpha$ mRNA precursors proceeds efficiently in response to external stimuli in early inflammation when PKR is available and is subject to regulation by PKR (Chiu and Yang, 2007).

Since IL-1 activates PKR in chondrocytes and IL-1 and OSM act synergistically to induce cartilage catabolism, the aim of this study was to delineate the role of PKR in mediating the cellular responses induced by the proinflammatory cytokine combination of OSM and IL-1 in bovine articular cartilage chondrocytes.

\section{Materials and Methods}

\section{Materials}

All chemicals were obtained from Sigma (Poole, UK) unless otherwise stated and were of analytical grade. Recombinant human IL- $1 \alpha$ and OSM were purchased from Peprotech EC (London, UK). Culture medium consisted of Dulbecco's Modified Eagle's Medium (1:1 mixture of DMEM-Glutamax-ITM and Ham's F12 media) containing $10 \mathrm{mM}$ HEPES pH 7.4, $100 \mathrm{U} / \mathrm{mL}$ penicillin, $100 \mu \mathrm{g} /$ $\mathrm{mL}$ streptomycin, $50 \mu \mathrm{g} / \mathrm{mL}$ ascorbate-2-phosphate and supplemented with 1x Insulin-transferrin-sodium selenite (ITS) (Invitrogen, Paisley, UK).

\section{Primary chondrocyte culture}

Full depth articular cartilage was taken from the metacarpophalangeal joints (from $\geq 4$ legs) of 7 day-old bovine calves within $6 \mathrm{~h}$ of slaughter using a scalpel. Chondrocytes were isolated by enzymatic digestion $(0.1 \%$ (w/v) pronase (Roche Applied Science, Burgess Hill, UK) in media containing $5 \%$ foetal calf serum (FCS) for $30 \mathrm{~min}$ followed by overnight incubation in $0.04 \%(\mathrm{w} / \mathrm{v})$ type II collagenase (Invitrogen) in media containing $5 \% \mathrm{FCS}$ at $37{ }^{\circ} \mathrm{C}$ in a humidified atmosphere of $5 \% \mathrm{CO}_{2}, 95 \%$ air. Following isolation, unless stated otherwise, chondrocytes were seeded at $1.0 \times 10^{6}$ cells per well of a 24 -well plate and cultured for $48 \mathrm{~h}$ at $37^{\circ} \mathrm{C}$ in $1 \mathrm{~mL}$ serum-free media. Media was supplemented with $1 \mathrm{x}$ ITS to maintain chondrocyte phenotype and prevent serum withdrawal activation of signalling pathways (Patel et al., 2000).

\section{Biochemical treatments}

After $48 \mathrm{~h}$, the media was replaced and chondrocytes cultured for $24 \mathrm{~h}$ prior to the direct addition of treatments to the existing media to prevent activation of the MAPK signalling pathway by changing the media (Gilbert et al., 2008). Initial experiments (confocal microscopy and protein concentration) examined whether PKR could be activated in vitro by $\mathrm{IL}-1(5 \mathrm{ng} / \mathrm{mL})$ and OSM $(10 \mathrm{ng} / \mathrm{mL})$ either alone or in combination. From these experiments, the combination of IL-1 (5 ng/mL)and OSM (10 ng/mL) was chosen as the treatment regime for subsequent experiments since it had the most potent effect. Chondrocytes were treated with cytokines for 7 days. Unstimulated, control chondrocytes were treated with media alone. To inhibit the activation of PKR, a potent selective small molecule inhibitor (PKRi; $1 \mu \mathrm{M}$; Merck Chemicals, Nottingham, UK) which binds to the ATP-binding site was added to replicate cultures $30 \mathrm{~min}$ prior to the addition of treatments (Jammi et al., 2003; Tam et al., 2007). In addition, an inactive version of the PKR inhibitor was added to replicate cultures as a negative control (PKRi neg; $1 \mu \mathrm{M}$; Merck Chemicals). All treatments and media were warmed to $37{ }^{\circ} \mathrm{C}$ before being added gently to cells. The media remained in place for the 7-day culture and no additional treatments were added during this period. At the end of the culture period, cells were lysed with $100 \mu \mathrm{L}$ ice-cold Triton X-100 (0.9\% v/v) containing protease inhibitors (Protease Inhibitor Cocktail Set I; Merck Chemicals) and phosphatase inhibitors (Phosphatase inhibitor cocktail Set III; Merck Chemicals). Cell extracts were stored at $-80{ }^{\circ} \mathrm{C}$ and media at $-20^{\circ} \mathrm{C}$.

\section{Total protein assay}

The total protein concentration of the cell extracts at the end of the 7-day culture period was analysed using the Pierce bicinchoninic acid (BCA) assay according to manufacturer's instructions (Thermo Fisher Scientific, Cramlington, UK).

\section{Cell number and toxicity}

Cell number and cell death over the culture period were determined using the CytoTox $96^{\circledR}$ assay according to manufacturer's instructions (Promega, Southampton, UK), which quantitatively measures lactate dehydrogenase $(\mathrm{LDH})$ present in the culture media that has been released upon death of cells during the culture period. This assay can also be used to measure indirectly the LDH activity present in the cytoplasm of cells that are intact at the end of the culture period. Cell quantification, therefore, occurs following lysis of the cells by the addition of extract buffer. The number of cells present is directly proportional to the absorbance value, which represents LDH activity. Absorbance at $490 \mathrm{~nm}$ was recorded for cell number and cell death after 10 and $30 \mathrm{~min}$, respectively.

\section{Gelatin substrate zymography}

MMP9 activity was detected in media samples by gelatin substrate zymography as described previously 
(Gilbert et al., 2004). Briefly, gelatin (porcine skin; VWR International, Lutterworth, UK) was incorporated into 7.5 $\%(\mathrm{w} / \mathrm{v})$ sodium dodecyl sulphate (SDS)-polyacrylamide gels at a final substrate concentration of $1.0 \mathrm{mg} / \mathrm{mL}$. Media samples (diluted 1:1 with 2x sample buffer), a recombinant MMP9 standard (Merck Chemicals), and protein molecular weight markers (Mr 14-200 kDa; BioRad Laboratories, Hemel Hempstead, UK) were loaded onto the gels and resolved by electrophoresis. Following electrophoresis, the gels were washed, with agitation, in $2.5 \%$ (v/v) Triton $\mathrm{X}-100$ for $1 \mathrm{~h}$ with at least 3 changes of solution and subsequently incubated for $16-20 \mathrm{~h}$ at $37{ }^{\circ} \mathrm{C}$ in proteolysis buffer. Gels were stained with Coomassie ${ }^{\circledR}$ Brilliant Blue R $250(2 \mathrm{~g} / \mathrm{L})$ in distilled water, methanol and acetic acid (4.5:4.5:1) for at least $1 \mathrm{~h}$, and destained in methanol, acetic acid, water $(1: 0.75: 8.25)$ until the zones of proteolysis had cleared. Molecular weight markers and standards facilitated identification of the enzymes and allowed comparisons between gels. Relative quantities of MMPs were measured by scanning densitometry (UMAX magic scan; Umax Colour Scanner, Willich, Germany), using image analysis software (NIH Image; National Institutes of Health, Bethesda, MD, USA; online at: http://rsb.info. nih.gov/nih-image/) and expressed as absorbance units per cell (Vaughan-Thomas et al., 2000).

\section{Western blot analysis}

Protein extracts, from an equivalent cell number, were reduced $(2.5 \% \mathrm{v} / \mathrm{v} \beta$-mercaptoethanol) and resolved on $10 \%(\mathrm{w} / \mathrm{v})$ SDS-polyacrylamide gels. For each analysis, control and treated samples were run on the same gel for direct comparison. Protein was transferred to PVDF membranes (Immobilon; Millipore, Watford, UK) and blocked for $1 \mathrm{~h}$ at room temperature in blocking buffer (Tris Buffered Saline with Tween 20 (TBST); $0.15 \mathrm{M}$ $\mathrm{NaCl}, 0.05 \mathrm{M}$ Tris/ $\mathrm{HCl} \mathrm{pH} 8.0,3 \%$ (w/v) skimmed milk powder, $0.05 \%$ (v/v) Tween 20). After washing (TBST), membranes were incubated for $2 \mathrm{~h}$ at room temperature with a monoclonal antibody to type II collagen (AVT6E3 (Vaughan-Thomas et al., 2008)) diluted in TBST. Membranes were washed (TBST) and then incubated for $1 \mathrm{~h}$ at room temperature in anti-mouse horseradish peroxidase conjugated IgG. Bands were detected using enhanced chemiluminescence reagents and HyperfilmECL (GE Healthcare Life Sciences, Little Chalfont, UK) and blots scanned (Umax Magic scan) and analysed by densitometry (NIH Image) (Vaughan-Thomas et al., 2000).

\section{Immunocytochemistry}

Immediately after isolation, chondrocytes were seeded onto 8 well glass chamber slides $\left(0.5 \times 10^{6}\right.$ cells/well $)$ and left for $48 \mathrm{~h}$ prior to stimulation as described above. Following treatment, cells were fixed in $2 \%(\mathrm{w} / \mathrm{v})$ paraformaldehyde and permeabilised in $0.2 \%(\mathrm{v} / \mathrm{v})$ Triton-X100. Each subsequent step was performed at room temperature unless stated otherwise and between each incubation step, sections were washed $3 \mathrm{x} 5 \mathrm{~min}$ in $0.01 \mathrm{M}$ phosphate buffered saline (PBS, pH 7.4) containing $0.001 \%$ Tween 20 (wash buffer). All antibodies were diluted in wash buffer. Cells were washed before blocking in $2 \%(\mathrm{v} / \mathrm{v})$ normal goat serum (Dako UK, Ely, UK) for $1 \mathrm{~h}$. After overnight incubation at $4{ }^{\circ} \mathrm{C}$ with a rabbit polyclonal phosphospecific primary antibody to active PKR [pT $\left.{ }^{446}\right]$ (Abcam, Cambridge, UK) diluted 1:100, cells were washed before incubating for $1 \mathrm{~h}$ with FITC-conjugated anti-rabbit antibody diluted 1:160. Cells were washed and blocked as before prior to incubation with a monoclonal antibody to Golgi matrix protein (anti-GM130; BD Transduction Laboratories, Oxford, UK) diluted 1:500. Cells were washed and a goat anti-mouse Alexa 594 conjugated secondary antibody (1:400 dilution; Molecular probes, Invitrogen) applied to the cells for $1 \mathrm{~h}$. Finally, after washing, cells were mounted in VECTASHIELD ${ }^{\circledR}$ Mounting Medium containing DAPI $(1.5 \mu \mathrm{g} / \mathrm{mL}$ ) to counterstain DNA (Vector Laboratories, Peterborough, UK). Representative cells from multiple fields of view were scanned with a Leica TCS SP2 confocal microscope (Leica, Heidelberg, Germany) using a $63 x$ oil immersion objective lens (x7.5 zoom) as described previously (Blain et al., 2006). To eliminate the possibility of spectral bleed-through between fluorescent probes, representative regions were scanned using appropriate excitation and emission settings for sequential recordings of DAPI (ex $\max 358 \mathrm{~nm}$; em $\max : 461 \mathrm{~nm}$ ), FITC (excitation max: $494 \mathrm{~nm}$; emission max: $518 \mathrm{~nm}$ ) and Alexa 594 (excitation max: 594 nm; emission max: 617 $\mathrm{nm})$. Maximum intensity, 3D projections were obtained by processing stacks of optical sections through the full depth of chondrocytes at a spacing of $0.5 \mu \mathrm{m}$. Since PKR is constitutively activated in sub-populations of chondrocytes in vitro (Gilbert et al., 2002; Blalock et al., 2009), untreated cultures served as positive controls. Negative controls where the primary antibody was omitted were devoid of fluorescent signal (data not shown).

\section{Quantitative PCR analysis of gene expression}

Immediately after isolation, chondrocytes were seeded at $0.5 \times 10^{6}$ cells per well of a 48 well plate and left for $48 \mathrm{~h}$ prior to stimulation as described above. At the end of the experiment, media were replaced with $0.5 \mathrm{~mL}$ of TRIZOL $^{\circledR}$ (Invitrogen) and total RNA extracted according to the manufacturer's instructions with the following exceptions. After the addition of chloroform, the entire RNA extraction mix was transferred to a tube containing Heavy Phase-lock Gel ${ }^{\mathrm{TM}}$ (Eppendorf ${ }^{\circledR}$; VWR International) and centrifuged at $13,000 \mathrm{~g}$ for $2 \mathrm{~min}$ at $4{ }^{\circ} \mathrm{C}$. The upper aqueous layer was removed to a new Eppendorf tube, an equal volume of isopropanol added and the RNA left to precipitate overnight at $-20^{\circ} \mathrm{C}$. At the end of the extraction protocol, the RNA was DNase treated to remove genomic DNA (Ambion; Applied Biosystems, Warrington, UK) and re-suspended in $50 \mu \mathrm{L}$ RNase-free water. cDNA was generated in a $20 \mu \mathrm{L}$ reaction from $11 \mu \mathrm{L}$ RNA using $250 \mathrm{ng}$ random hexamers $(0.5 \mathrm{mg} / \mathrm{mL}$; Promega) and Superscript III reverse transcriptase (200 units; Invitrogen).

Gene expression was measured by SYBR green quantitative PCR (qPCR) using the MX3000PTM qPCR system according to manufacturer's instructions (Stratagene $^{\circledR}$; Agilent Technologies UK, Stockport, UK) with $200 \mathrm{nM}$ forward and reverse primers (Table 1) annealing at $60{ }^{\circ} \mathrm{C}$ (except MMP13 and MMP9 which annealed at $58^{\circ} \mathrm{C}$ and $62{ }^{\circ} \mathrm{C}$, respectively). Fold changes relative to untreated cells were calculated using the 
Table 1. Quantitative PCR primers

\begin{tabular}{|c|c|c|c|}
\hline Gene & Strand & Sequence & Reference/Accession No. \\
\hline $\begin{array}{l}\text { RN18S1 } \\
\text { (18s ribosomal 1) }\end{array}$ & $\begin{array}{l}\text { Forward } \\
\text { Reverse }\end{array}$ & $\begin{array}{l}\text { 5'-GCAATTATTCCCCATGAACG-3', } \\
\text { 5'- GGCCTCACTAAACCATCCAA-3' }\end{array}$ & (Frye et al. 2005) \\
\hline $\begin{array}{l}\text { COL2A1 } \\
\text { (Type II collagen) }\end{array}$ & $\begin{array}{l}\text { Forward } \\
\text { Reverse }\end{array}$ & $\begin{array}{l}\text { 5'-AACGGTGGCTTCCACTTC-3' } \\
\text { 5'-GCAGGAAGGTCATCTGGA-3' }\end{array}$ & (Darling and Athanasiou 2005) \\
\hline $\begin{array}{l}\text { COL9A1 } \\
\text { (Type IX collagen) }\end{array}$ & $\begin{array}{l}\text { Forward } \\
\text { Reverse }\end{array}$ & $\begin{array}{l}\text { 5'-CGCCCAAGGTTCCCTGTT-3' } \\
\text { 5'-ACTTGTAAGCCACCTGTAAGGCA-3' }\end{array}$ & AF419343 \\
\hline $\begin{array}{l}\text { COL11A1 } \\
\text { (Type XI collagen) }\end{array}$ & $\begin{array}{l}\text { Forward } \\
\text { Reverse }\end{array}$ & $\begin{array}{l}\text { 5'-AAAACCTGCCCCAGAAGACTATC-3' } \\
\text { 5'-AAAATCCTTGTCCCAAAAACCATA-3' }\end{array}$ & AY275644 \\
\hline $\begin{array}{l}A C A N \\
\text { (Aggrecan) }\end{array}$ & $\begin{array}{l}\text { Forward } \\
\text { Reverse }\end{array}$ & $\begin{array}{l}\text { 5'-GCTACCCTGACCCTTCAT-3' } \\
\text { 5'-AAGCTTTCTGGGATGTCCAC-3' }\end{array}$ & (Darling and Athanasiou 2005) \\
\hline SOX 9 & $\begin{array}{l}\text { Forward } \\
\text { Reverse }\end{array}$ & $\begin{array}{l}\text { 5'-AGTACCCGCACCTGCACAAC-3' } \\
\text { 5'-TCGTTCAGCAGTCTCCAGAGC-3' }\end{array}$ & AF278703 \\
\hline$T N F \alpha$ & $\begin{array}{l}\text { Forward } \\
\text { Reverse }\end{array}$ & $\begin{array}{l}\text { 5'-CATCCTGTCTGCCATCAAGA-3' } \\
\text { 5'-GGCGATGATCCCAAAGTAGA-3' }\end{array}$ & NM173966 \\
\hline МMP9 & $\begin{array}{l}\text { Forward } \\
\text { Reverse }\end{array}$ & $\begin{array}{l}\text { 5'-TAGCACGCACGACATCTTTC-3' } \\
\text { 5'-GAAGGTCACGTAGCCCACAT-3' }\end{array}$ & NM174744 \\
\hline MMP13 & $\begin{array}{l}\text { Forward } \\
\text { Reverse }\end{array}$ & $\begin{array}{l}\text { 5'-CCCTTGATGCCATAACCAGT-3' } \\
\text { 5'-GCCCAAAATTTTCTGCCTCT-3' }\end{array}$ & (Blain et al. 2010) \\
\hline ADAMTS4 & $\begin{array}{l}\text { Forward } \\
\text { Reverse }\end{array}$ & $\begin{array}{l}\text { 5'-CTCCATGACAACTCGAAGCA-3' } \\
\text { 5'-CTAGGAGACAGTGCCCGAAG-3' }\end{array}$ & (Blain et al. 2010) \\
\hline ADAMTS5 & $\begin{array}{l}\text { Forward } \\
\text { Reverse }\end{array}$ & $\begin{array}{l}\text { 5'-CTCCCATGACGATTCCAAGT-3' } \\
\text { 5'-TACCGTGACCATCATCCAGA-3' }\end{array}$ & (Blain et al. 2010) \\
\hline
\end{tabular}

$\Delta \Delta \mathrm{C}_{\mathrm{T}}$ method with RN18S1 (18S ribosomal) RNA as the reference gene (Frye et al., 2005). All primers were purchased from MWG and validated using a standard curve of five serial dilutions so that all primer efficiencies were between 90-110\% (Taylor et al., 2010).

\section{Data analysis}

Data are presented as mean \pm SEM and tested for normality and equal variances prior to analysis (Minitab). Data were analysed by general linear model analysis of variance (GLM ANOVA) followed by Tukey's post hoc test. Comparisons were made to untreated, control cells unless otherwise stated and differences considered significant at $p \leq 0.05$. Each experiment consisted of 4-6 replicates per treatment where one replicate was a single well of a tissue culture plate. To ensure a heterogeneous population of cells for each experiment, cells were extracted from a pool of cartilage taken from a minimum of 4 bovine legs. Experiments were repeated once to ensure reproducibility of results and representative data from 1 experiment shown. Since the qPCR data for ADAMTS5 mRNA was more variable than other data sets, data from the 2 experiments were combined for analysis.

\section{Results}

Active PKR is localised within the cytoplasm of articular chondrocytes

After 7-days of culture, chondrocytes were fixed and labelled for phosphorylated (active) PKR (Fig. 1). In unstimulated chondrocytes diffuse staining for phosphorylated PKR was observed throughout the cytoplasm (Fig. 1a). In addition, a perinuclear pool of active PKR was also observed in some cells (Fig. 1b), which co-localised with staining for the Golgi marker, GM130 (Fig. 1c). The localisation of active PKR in the cytoplasm was similar in cells that had been cultured in the presence of IL-1 (Fig. 1d-f), OSM (Fig. $1 \mathrm{~g}-\mathrm{i}$ ) or a combination of OSM+IL-1 (Fig. 1j-1).

\section{Il-1 and OSM, in combination, potently reduces cellular protein concentration through a PKR dependent mechanism}

To determine whether each cytokine treatment activated PKR and resulted in reduced translation, the protein concentration of cell extracts was determined in the presence or absence of the small molecule PKR inhibitor after 7 days (Fig. 2). Only the combined treatment with IL-1+OSM significantly reduced protein concentration ( $p \leq 0.01$ vs. untreated control cells). Inhibition of PKR reversed the effect of OSM+IL-1, returning the protein concentration to that of untreated, control cells $(p \leq 0.01)$. Subsequent experiments used only the combination of OSM+IL-1 as the treatment regime since was the only significant PKR mediated effect.

\section{Inhibition of PKR enhances the OSM and IL-1 induced increase in chondrocyte proliferation} After 7-days in culture, OSM+IL-1 treatment resulted in a trend towards increased chondrocyte proliferation (Fig. $3 \mathrm{a} ; p=0.07)$. To investigate whether this increase occurred through activation of PKR, duplicate cultures were treated 

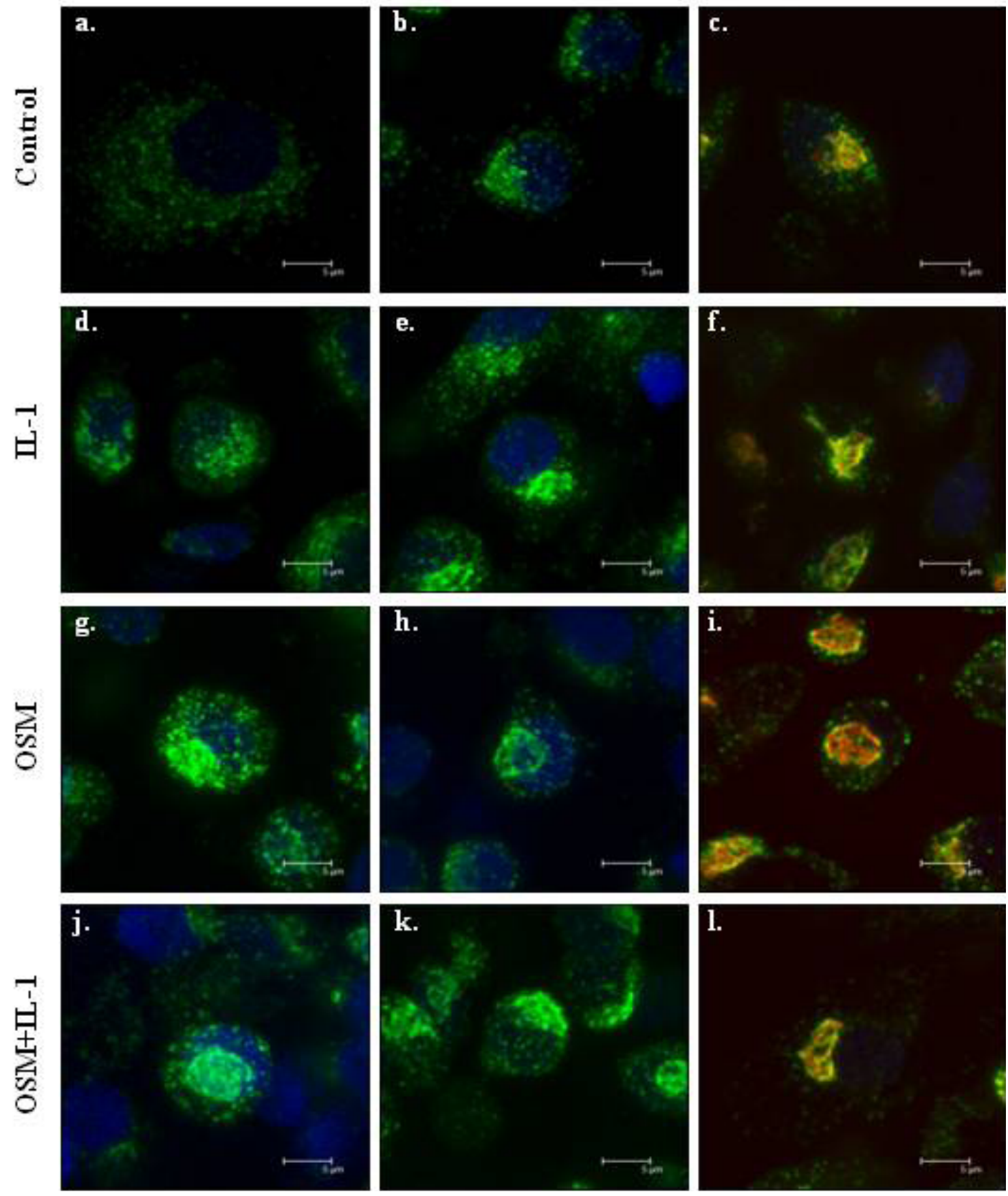

Fig. 1. Active PKR is localised within the cytoplasm of articular chondrocytes. The subcellular localisation of phosphorylated PKR (FITC green) and Golgi matrix protein (AlexaFluor red) was determined by immunocytochemistry. Representative cells from multiple fields of view were imaged by confocal microscopy with appropriate settings for FITC (green), AlexaFluor 594 (red) and DAPI nuclear counterstain (blue). Maximum intensity 3D reconstructions are shown. Staining for phosphorylated PKR was observed throughout the cytoplasm of untreated, control cells (a) and within peri-nuclear pools (b). Areas of green PKR and red Golgi co-localisation can be observed as yellow staining (c). Treatment with IL-1 (d-f), OSM (g-i) or a combination of OSM+IL-1 (j-l) did not alter the localisation of active PKR.

with the small molecule PKR inhibitor. Inhibition of PKR resulted in an increase in basal proliferation levels $(p<$ $0.05)$. Pre-treatment with this inhibitor prior to the addition of OSM+IL-1 greatly enhanced the cytokine-induced increase in proliferation $(p<0.001 v s$. untreated controls; $p<0.01$ vs. OSM/IL-1 alone).
Increased chondrocyte death induced by combined treatment of OSM and IL-1 is not due to activation of PKR

Media was assessed for the level of LDH release as an indicator of cell death over the 7-day culture period (Fig. $3 b)$. Treatment with OSM+IL-1 for 7-days resulted in a significant increase in chondrocyte death $(p<0.001 v s$. 


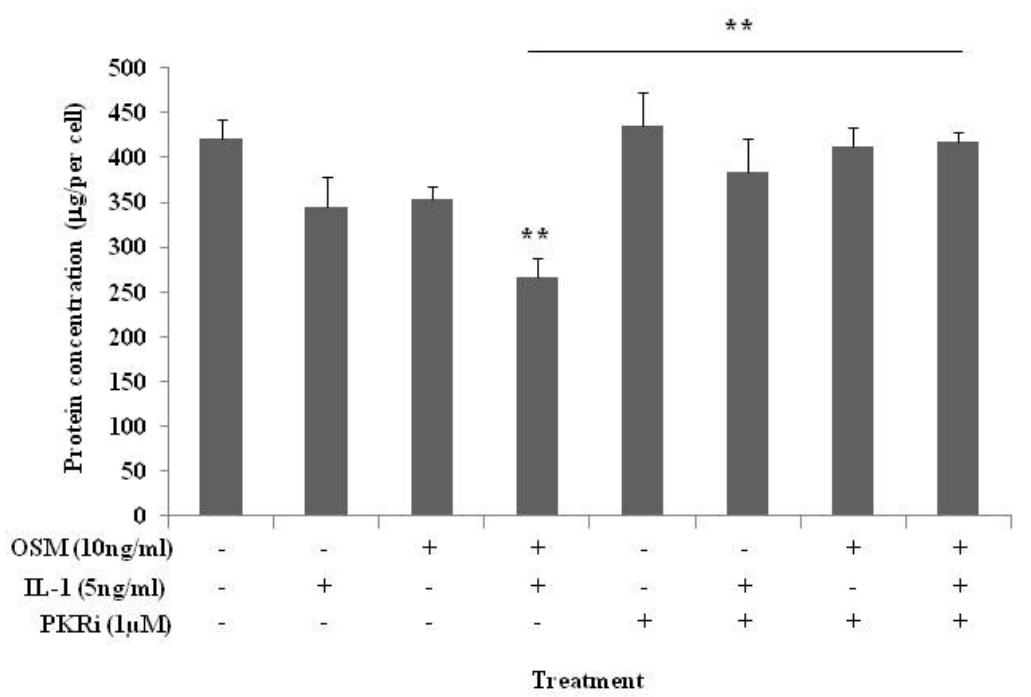

Fig. 2. The combination of OSM+IL-1 potently reduces cellular protein concentration through a PKR dependent mechanism. At the end of the 7-day culture period, cells were lysed and the protein concentration of the cell extract determined by BCA assay. Data is presented normalised to cell number equivalent assessed by LDH assay (mean $\pm \mathrm{SEM} ; n=6$ per treatment) and analysed by GLM ANOVA and Tukey's post hoc test: **p $<0.01$ vs. untreated controls unless shown otherwise.

untreated controls). Inhibition of PKR had no significant effect on basal or cytokine-induced cell death.

OSM and IL-1 increase the expression and activation of MMP9 in primary articular chondrocytes through activation of PKR

The cytokine combination of OSM and IL-1 has previously been shown to up-regulate MMP9 expression and activation in nasal cartilage (Milner et al., 2006) and articular cartilage (Blain et al., 2010). We therefore assessed whether these cytokines could increase MMP9 expression and/or activation in articular chondrocytes via a mechanism involving PKR. Media was analysed for MMP9 by gelatin substrate zymography (Fig. 4a,b). Low levels of proMMP9 were detected in the media from untreated, control chondrocytes after 7 days in culture. In contrast, OSM+IL-1 resulted in a 7.8-fold up-regulation of proMMP9 ( $p<0.001 v s$. untreated controls following $\log$ transformation of data). Pre-treatment with the PKR inhibitor completely blocked the basal expression of MMP9 ( $p<0.001 v s$. untreated controls following log transformation of data). Addition of the inhibitor prior to treatment with OSM+IL-1 resulted in a 2.5-fold reduction in proMMP9 expression ( $p=0.05 v s$. OSM+IL-1 alone following log transformation of data) although levels remained 3-fold higher than those detected in control cultures ( $p=0.01$ following $\log$ transformation of data). No active MMP9 was detected in untreated, control cultures. In contrast, high levels of MMP9 activation were observed in cultures following OSM+IL-1 treatment. This OSM+IL-1induced activation of MMP9 was completely abolished by addition of the PKR inhibitor. The PKR inhibitor negative control (PKRi neg) had no effect on cytokine-induced MMP9 levels (data not shown).

$M M P 9$ mRNA expression was also analysed by qPCR (Fig. 4c). OSM+IL-1 treatment increased $M M P 9$ mRNA expression 8.9-fold over untreated controls $(p<0.01$ following ranking of data). The PKR inhibitor reduced basal MMP9 mRNA expression by 24 -fold ( $p<0.001$ $v s$. untreated controls following ranking of data) and significantly reduced the OSM+IL-1 treated group to 8.9-fold below the basal expression level $(p<0.001 v s$. untreated controls; $p<0.001 v s$. OSM+IL-1 following ranking of data). The PKR inhibitor negative control (PKRi neg) had no effect on cytokine-induced $M M P 9$ mRNA levels.

\section{OSM and IL-1 increase the expression of MMP13 mRNA in articular chondrocytes through a PKR independent mechanism}

Several studies have shown that treatment of chondrocytes with OSM and IL-1 results in the up-regulation of MMP13 mRNA expression (Koshy et al., 2002; Barksby et al., 2006; Milner et al., 2006; Blain et al., 2010). To determine whether this increase was mediated through the PKR pathway, the expression of MMP13 mRNA was assessed by qPCR following OSM+IL-1 treatment and PKR inhibition (Fig. 5). OSM+IL-1 treatment resulted in a 73-fold increase in MMP13 mRNA over untreated controls $(p<0.001$ following $\log$ transformation of data). Inhibition of PKR had no significant effect on basal or cytokine-induced MMP13 mRNA expression. The PKR inhibitor negative control (PKRi neg) had no effect.

The OSM and IL-1 induced increase in the expression of $A D A M T S 4$ and $A D A M T S 5$ mRNAs in primary articular chondrocytes is mediated, through activation of PKR

Since OSM and IL-1 treatment of chondrocytes increases the expression of ADAMTS4 and 5 (Koshy et al., 2002; Young et al., 2005; Milner et al., 2006; Durigova et al., 2008; Durigova et al., 2011), we determined whether this 
(a)

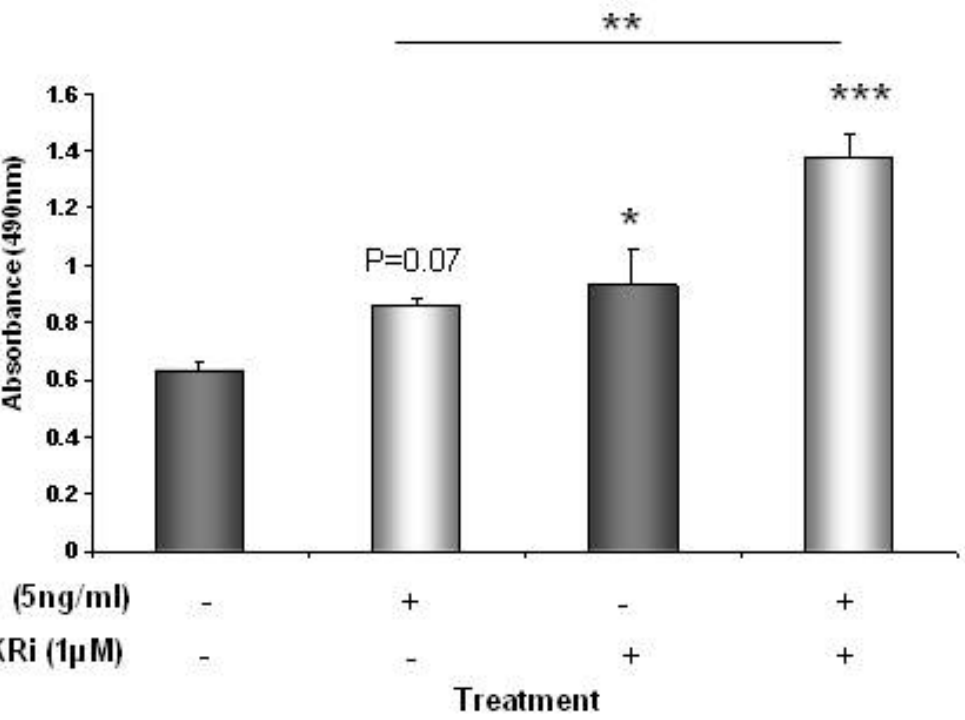

(b)

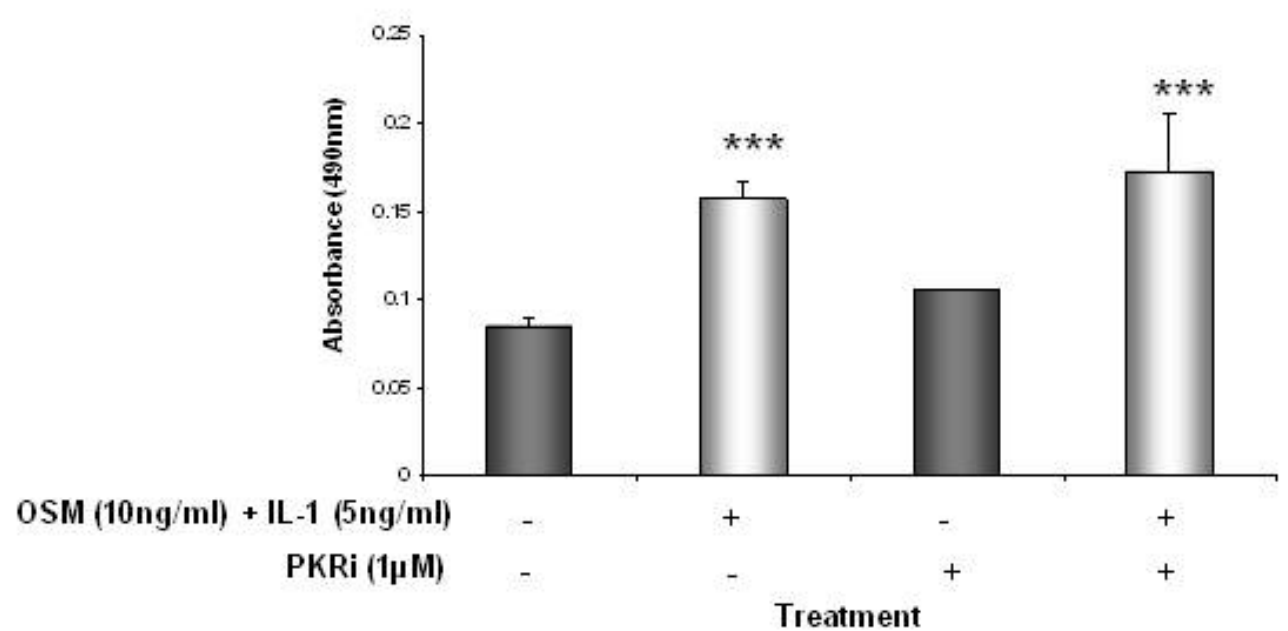

Fig. 3. Inhibition of PKR enhances the effect of OSM and IL-1 on chondrocyte proliferation but not cell death. (a) At the end of the culture period, cells were lysed and the relative cell number determined by measuring LDH activity. The number of cells present is directly proportional to the absorbance value, which represents LDH activity. (b) Media were assessed for the level of LDH released over the culture period as a measure of cell death. Data are presented as mean \pm SEM ( $n=4$ per treatment) and analysed by GLM ANOVA and Tukey's post hoc test: ${ }^{*} p \leq 0.05 ; * * p<0.01 ; * * * p<0.001 v s$. untreated controls unless shown otherwise.

involved PKR, by assessing the expression of ADAMTS4 and 5 following OSM+IL-1 treatment and PKR inhibition (Fig. 6; data ranked prior to analysis). OSM+IL-1 treatment resulted in a 754-fold increase in ADAMTS4 $(p<0.001$, Fig. 6a) and a 40.8-fold increase in ADAMTS5 mRNAs ( $p<0.001$, Fig. 6b) compared to untreated control cells. Inhibition of PKR significantly reduced basal ADAMTS4 and ADAMTS5 ( $p<0.05$ Fig. 6). Inhibition of PKR in cytokine treated cultures resulted in an 8.5-fold reduction in ADAMTS4 mRNA compared to OSM+IL-1 alone (Fig. 6a; $p<0.01)$ although ADAMTS4 still remained 88-fold higher than control expression levels $(p<0.001)$. PKR inhibition also significantly reduced ADAMTS5 mRNA expression in OSM+IL-1 treated cultures (Fig. 6b; 3.8-fold reduction $p$ $<0.001$ compared with OSM+IL-1 alone) although levels still remained 10.7-fold higher than controls (Fig. 6b; $p<$
0.001). The PKR inhibitor negative control (PKRi neg) had no effect on cytokine-induced ADAMTS4 (Fig. 6a) or ADAMTS5 (data not shown) levels.

\section{The OSM and IL-1 down-regulation of type II collagen in articular chondrocytes is enhanced by PKR inhibition}

Cell extracts were examined for type II collagen expression by qPCR (Fig. 7a) and Western blot (Fig. 7b) analysis. After 7-days in culture, inhibiting PKR had no effect on the basal level of COL2A1 mRNA. Cytokine treatment resulted in a significant, 11 -fold reduction in the expression of COL2A1 mRNA compared to untreated control cells (Fig. 7a; $p<0.001$ following log transformation of data). Inhibition of PKR in cytokine treated cultures resulted in a 41-fold reduction in the level of COL $2 A 1$ mRNA compared 
(a)

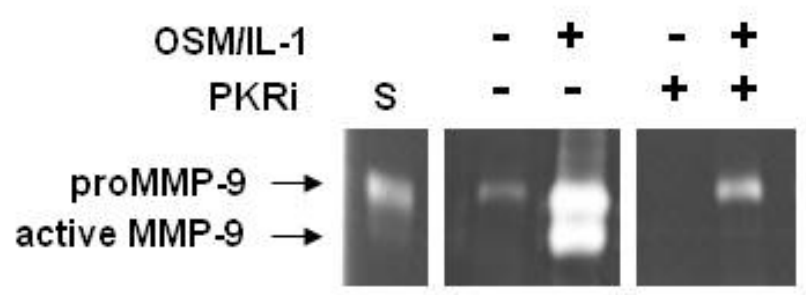

(b)

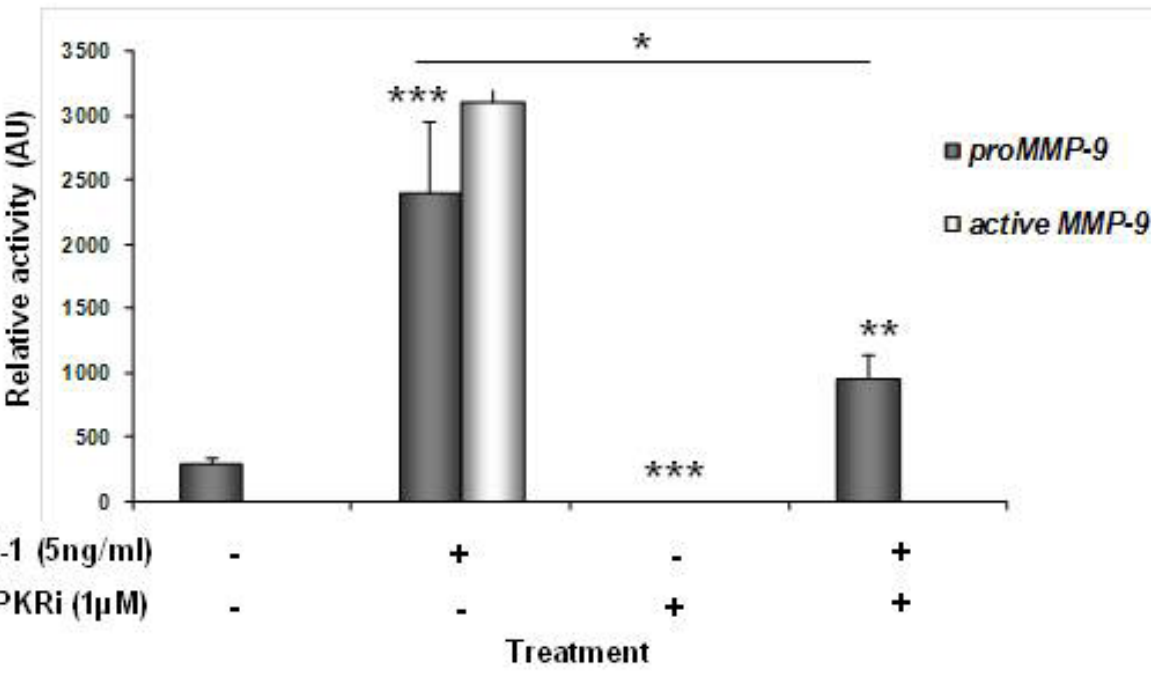

(c)

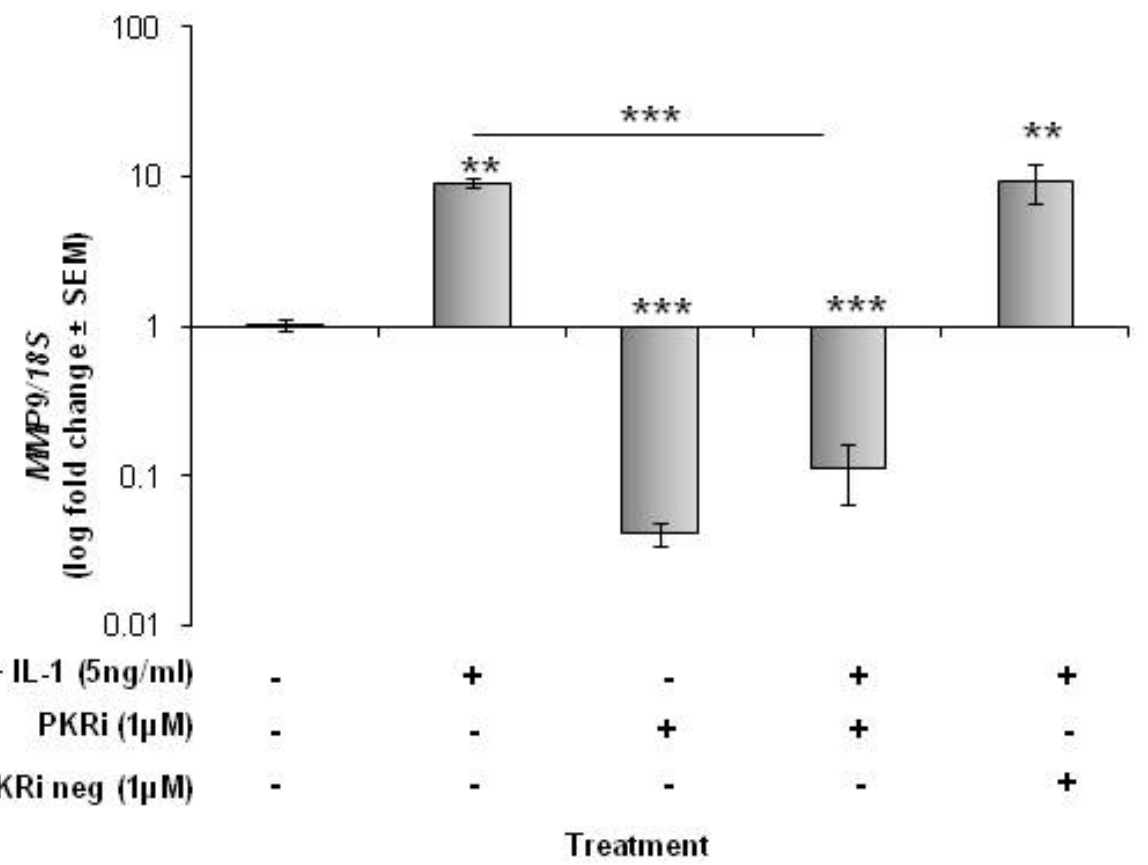

Fig. 4. OSM and IL-1 treatment increases the expression and activation of MMP9 via activation of PKR. (a) Media were collected at the end of the 7-day treatment period and analysed by gelatin substrate zymography. A proMMP9 standard (s) is indicated. (b) The area (absorbance units) of substrate gel cleared by pro- and active MMP9 was measured by scanning densitometry. Data shown are absorbance units per cell, expressed as means \pm SEM $(n=$ 4 per treatment) and analysed by GLM ANOVA and Tukey's post hoc test: *** $p<0.001 ; * * p<0.01 ; * p \leq 0.05 v s$. untreated controls unless shown otherwise. (c) RNA from cells ( $n=6$ per treatment) was analysed by quantitative PCR to determine the relative expression of $M M P 9$ mRNA. Data are presented as fold change relative to untreated control cells calculated using the $\Delta \Delta \mathrm{C}_{\mathrm{T}}$ method with RN18S1 (18S ribosomal) RNA as the reference gene and plotted as mean \pm SEM. Data were ranked prior to analysis and significant differences detected by GLM ANOVA and Tukey's post hoc test: $* * * p<0.001 ; * * p<0.01 v s$. untreated controls unless shown otherwise. 


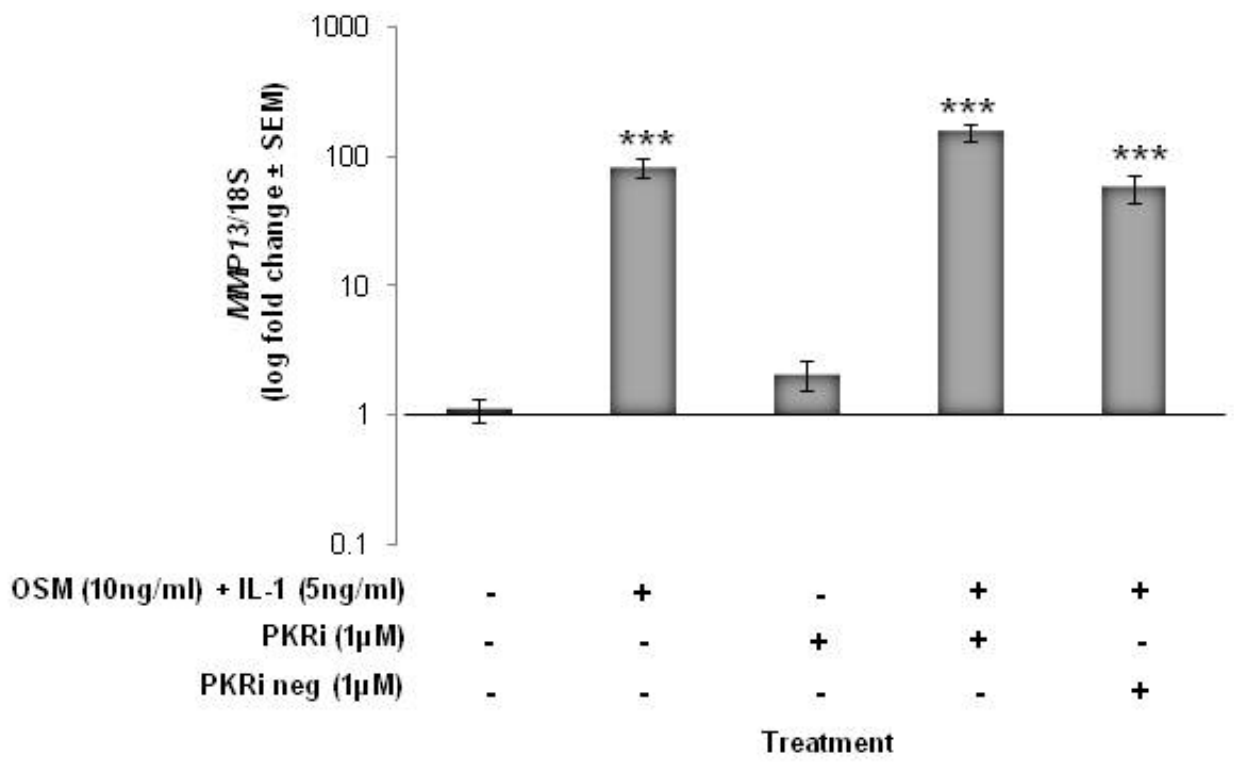

Fig. 5. OSM and IL-1 treatment increases the expression of MMP-13 through a PKR independent mechanism. RNA from cells ( $n=3-6$ per treatment) was analysed by quantitative PCR to determine the relative expression of $M M P 13$ mRNA. Data are presented as fold change relative to untreated control cells calculated using the $\Delta \Delta \mathrm{C}_{\mathrm{T}}$ method with RN18S1 RNA as the reference gene and plotted as mean \pm SEM. Significant differences were detected by GLM ANOVA and Tukey's post hoc test on $\log$ transformed data: $* * * p<0.001$ vs. untreated controls.

to untreated control cultures $(p<0.001$ following $\log$ transformation of data) and 3.5-fold reduction compared to cytokine treatment alone $(p<0.01$ following $\log$ transformation of data); a finding that was reproduced to the same level in the experimental repeat. The PKR inhibitor negative control (PKRi neg) had no effect on cytokine treated cells.

A complete loss of type II collagen protein was consistently observed in all samples analysed following OSM+IL-1 treatment ( $n=4$ samples; 2 independent experiments, Fig. 7b). Inhibiting PKR had no effect on the basal level of type II collagen protein or that observed in OSM+IL-1 treated chondrocytes. The PKR inhibitor negative control (PKRi neg) had no effect (data not shown).

\section{Treatment of chondrocytes with OSM and IL-1} decrease mRNA expression of genes that maintain the chondrocytic phenotype

The expression level of COL9A1 and COL11A1, and $A C A N$ mRNAs were assessed by qPCR (Fig. 8). OSM+IL-1 treatment resulted in a 3500-fold reduction in the expression of COL9A1 mRNA (Fig. 8a; $p<0.001$ following $\log$ transformation of data). Inhibition of PKR had no significant effect on the level of COL9A1 mRNA. Cytokine treatment also significantly reduced the expression of COL11A 15-fold compared to control levels (Fig. 8b; $p<0.001$ following log transformation of data). When cytokine stimulated cells were incubated with the PKR inhibitor, a further 4-fold reduction in the amount of COL11A1 mRNA was detected compared with OSM + IL-1 alone ( $p=0.001$ following $\log$ transformation of data). A 3.8-fold reduction in the level of $A C A N$ mRNA was detected in cells treated with cytokines which was reduced a further 10-fold following inhibition of PKR (Fig. 8c; $p<0.001$ after log transformation of data). The finding that PKR inhibition further reduced $C O L 11 A 1$ and $A C A N$ gene expression was reproduced to the same extent in both experimental repeats. No significant difference was observed in the level of SOX9 mRNA following any of the treatments (data not shown). The PKR inhibitor negative control (PKRi neg) did not alter the response of the cells to OSM+IL-1.

\section{Cytokine-induced increases in TNF $\alpha$ expression occurs through a mechanism involving PKR}

Since PKR regulates TNF $\alpha$ transcription (Kaempfer, 2003; Gilbert et al., 2006b) we determined whether TNF $\alpha$ mRNA expression was affected by the combined treatment of OSM and IL-1 and if so, whether this occurred through a mechanism involving PKR (Fig. 9). OSM and IL-1 stimulation of articular chondrocytes resulted in a 10.6-fold increase in $T N F \alpha$ mRNA compared to untreated control cells ( $p<0.001$ following log transformation of data). The basal expression level of $T N F \alpha$ mRNA was significantly reduced 1.9-fold following inhibition of PKR $(p<0.05$ following $\log$ transformation of data). In addition, $T N F \alpha$ mRNA expression in cytokine treated cultures was reduced 3.5 -fold by inhibiting PKR $(p<0.001$ following log transformation of data). Despite this significant reduction, levels still remained 3-fold higher than that detected in control cells $(p<0.001$ following log transformation of data). The PKR inhibitor negative control (PKRi neg) did not alter the response of the cells to OSM+IL-1 (data not shown). 

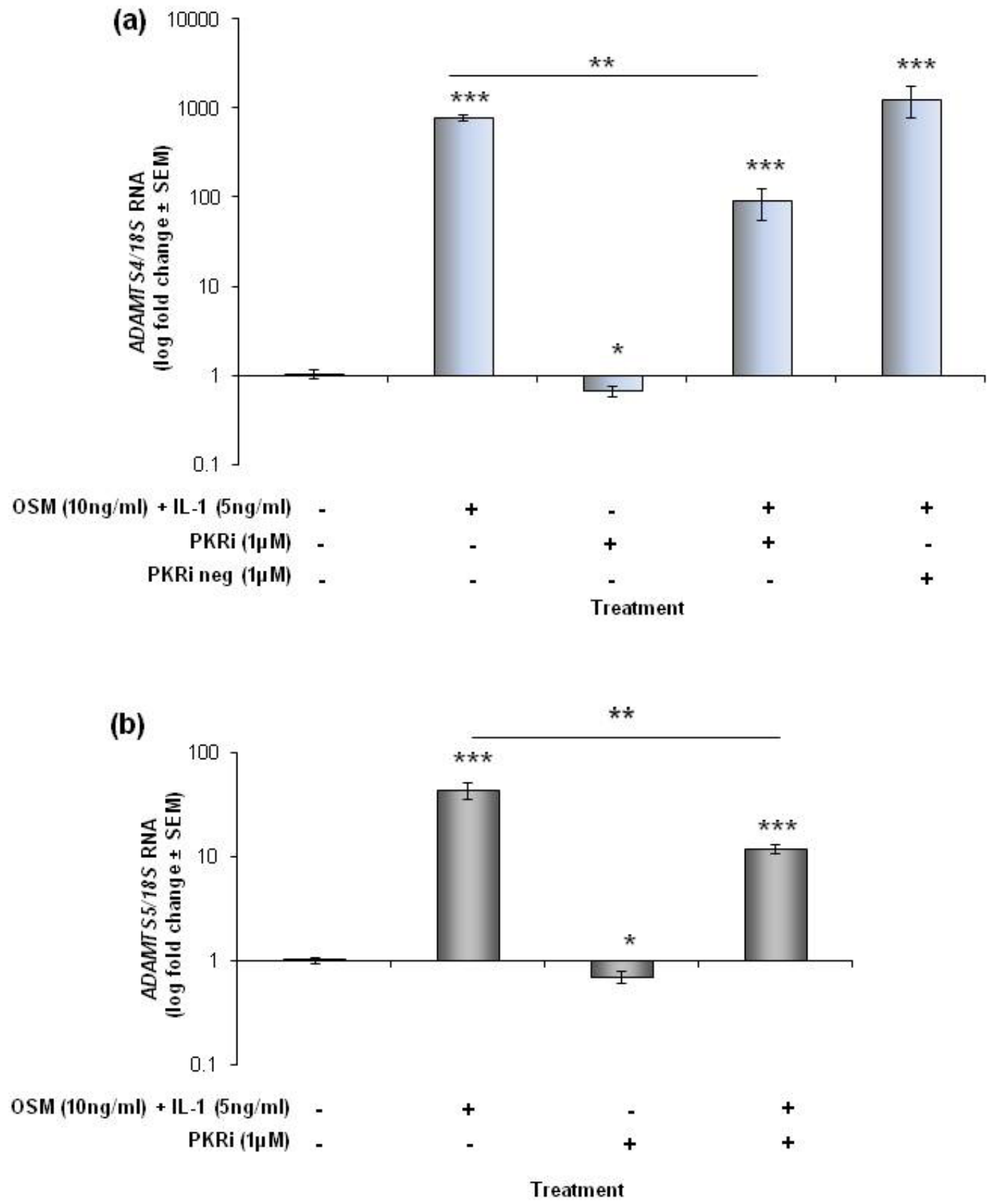

Fig. 6. OSM and IL-1 treatment increases the expression of ADAMTS-4 and ADAMTS-5 via activation of PKR. RNA from cells ( $n=6$ per treatment) was analysed by quantitative PCR to determine the relative expression of ADAMTS4 (a) and ADAMTS5 (b) mRNA. Data are presented as fold change relative to untreated control cells calculated using the $\Delta \Delta \mathrm{C}_{\mathrm{T}}$ method with RN18S1 RNA as the reference gene and plotted as mean \pm SEM. Significant differences were detected by GLM ANOVA and Tukey's post hoc test: *** $p<0.001 ; * * p<0.01 ; * p \leq 0.05$ vs. untreated controls unless shown otherwise. Data were ranked prior to analysis.

\section{Discussion}

This study investigated the mechanism behind the well documented synergistic effect of OSM and IL-1 on cartilage destruction. The stress-induced PKR signalling pathway is activated in early osteoarthritis and is involved in the propagation of proinflammatory signals in articular cartilage (Gilbert et al., 2002; Gilbert et al., 2004; Tam et al., 2007). Therefore, we investigated the role of PKR in the OSM and IL-1 induced catabolic phenotype in primary articular chondrocytes.

Immunohistochemistry using an antibody to the phosphorylated (active) form of PKR revealed that in unstimulated chondrocytes, active PKR was localised diffusely throughout the cytoplasm and within distinct peri-nuclear pools that co-localised with the Golgi. The localisation of active PKR did not alter following cytokine treatment. PKR is largely associated with 
(a)

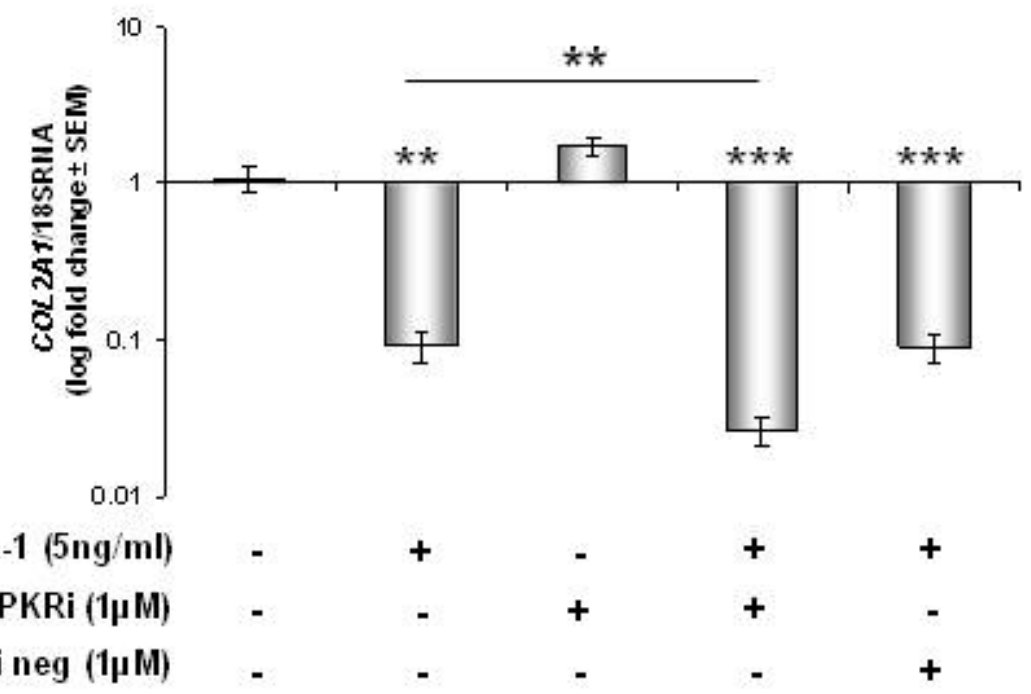

Treatment

(b)

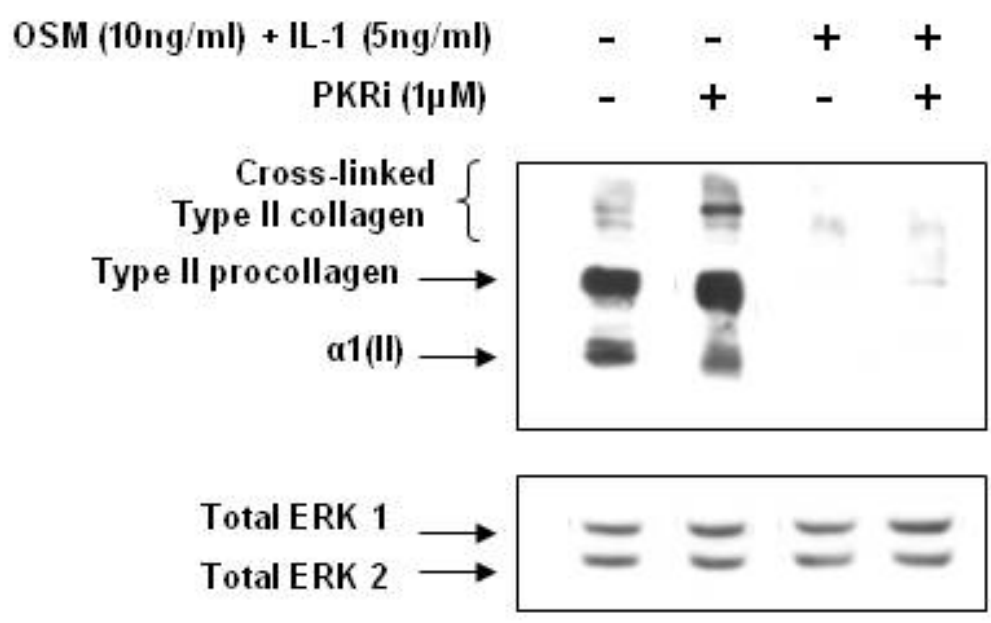

Fig. 7. The effect of cytokine treatment on type II collagen expression is enhanced following inhibition of PKR. Chondrocytes were treated for 7 days with OSM and IL-1 in the presence or absence of the PKR inhibitor. (a) Relative expression of COL2A1 (type II collagen) mRNA, determined by quantitative PCR, is presented as fold change relative to untreated control cells calculated using the $\Delta \Delta \mathrm{C}_{\mathrm{T}}$ method with RN18S1 RNA as the reference gene. Data are plotted as mean \pm SEM ( $n=6$ replicates per treatment). Significant differences were detected by GLM ANOVA and Tukey's post hoc test on log transformed data: *** $p<0.001 ; * * p<0.01$. (b) Protein from an equivalent cell number was analysed by Western blotting for type II collagen $(n=4$ replicates per treatment, representative data shown from 2 independent experiments). $\alpha 1(\mathrm{II})=$ alpha 1 chain type II collagen. Blots were stripped and re-probed for total ERK1/2 to confirm equivalent loading.

ribosomes in the cytoplasm and the rough endoplasmic reticulum (MacQuillan et al., 2009) but also localises to the juxta-nuclear cytoplasmic layer, the nuclear envelope and within the nucleus itself (Jeffrey et al., 1995; Besse et al., 1998). Localisation of active PKR within the cytoplasm is necessary for access to its substrates such as eIF2 $\alpha$ associated with the ribosomes (Zhu et al., 1997) and the IKK complex that releases I $\mathrm{B} \alpha \alpha$, the inhibitor of kappa Bto allow the translocation of nuclear factor kappa B (NFкB) to the nucleus (Kumar et al., 1994). At the time point analysed, we did not detect phosphorylated PKR in the nucleus after OSM or IL-1 individual or combined treatment. Interferon treatment of peripheral blood mononuclear cells for $24 \mathrm{~h}$ increases the amount of active PKR in the nucleus (MacQuillan et al., 2009). The role of PKR in the nucleus is less well defined but may involve ribosome biogenesis (Jimenez-Garcia et al., 1993), regulation of the amount of RNA molecules released into the cytoplasm (Besse et al., 1998), and enhancement of TNF $\alpha$ precursor transcript splicing (Osman et al., 1999). 
(a)

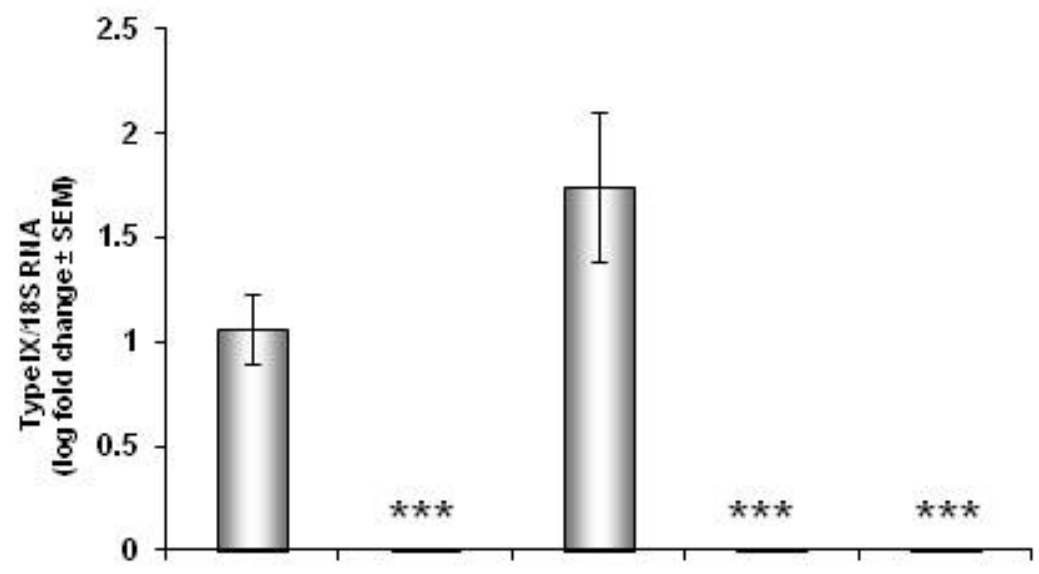

(b)

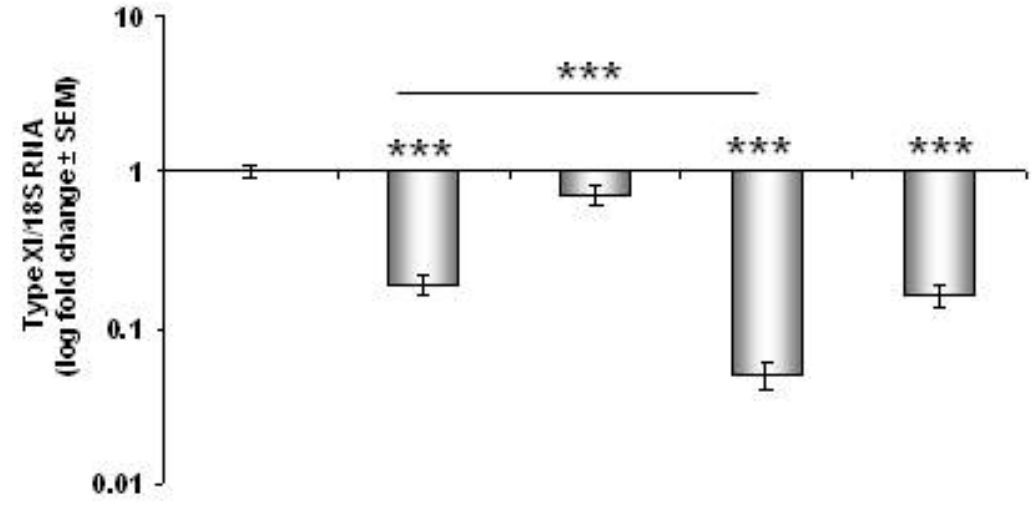

(c)

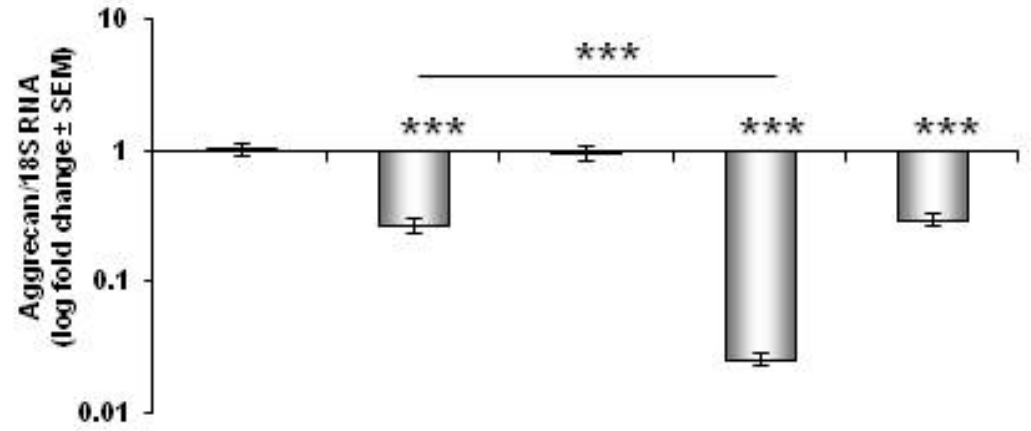

$\operatorname{OSM}(10 \mathrm{ng} / \mathrm{ml})+\mathrm{IL}-1(5 \mathrm{ng} / \mathrm{mI})$
PKRi $(1 \mu \mathrm{M})$
PKRi neg $(1 \mu \mathrm{M})$

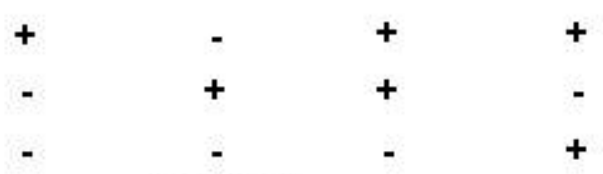

Treatment

Fig. 8. Combined treatment of chondrocytes with OSM and IL-1 results in a decrease in the expression of matrix genes that are important in maintaining a chondrocytic phenotype. Quantitative PCR was used to determine the relative expression of (a) COL9A1 (type IX collagen), (b) COL11A1 (type XI collagen), and (c) $A C A N$ (aggrecan) mRNA. Data are presented as fold change relative to control cells calculated using the $\Delta \Delta \mathrm{C}_{\mathrm{T}}$ method with $\mathrm{RN} 18 \mathrm{~S} 1$ RNA as the reference gene and plotted as mean $\pm \operatorname{SEM}(n=6$ replicates per treatment). Significant differences were detected by GLM ANOVA and Tukey's post hoc test on log transformed data: *** $p<0.001$ vs. untreated controls.

Future studies are clearly warranted, assessing earlier time points and co-localising active PKR with specific subcellular compartments in order to shed light on the roles of PKR following cytokine treatments.

To indicate the extent of PKR activation after individual or combination cytokine treatments, we measured total protein concentration under each treatment regime after
7 days (Fig. 2). Since active PKR blocks translation in response to stress signals (Clemens et al., 2000), the amount of total protein within the cell can be measured following cytokine treatment in the presence/absence of a PKR inhibitor to provide an indicator of the extent of PKR activation (Gilbert et al., 2006a; Scheuner et al., 2006). These data clearly show that only the combination of 


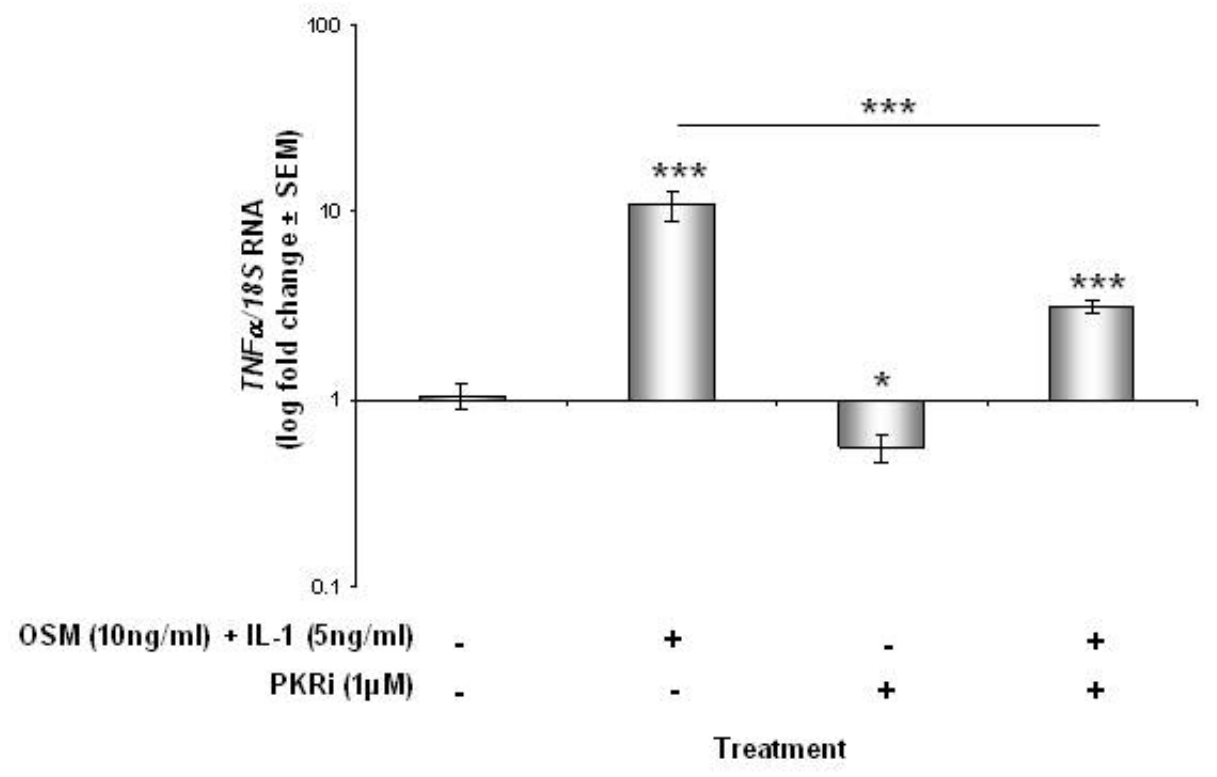

Fig. 9. Cytokine-induced increases in the expression of $T N F \alpha$ mRNA occurs through a mechanism involving PKR. TNF $\alpha$ mRNA expression analysed by quantitative PCR presented as fold change relative to control cells calculated using the $\Delta \Delta \mathrm{C}_{\mathrm{T}}$ method with RN18S1 RNA as the reference gene and plotted as mean \pm SEM $(n=6$ per treatment). Significant differences were detected by GLM ANOVA and Tukey's post hoc test on log transformed data: $* * * p<0.001 ; * p \leq 0.05 v s$. untreated controls unless shown otherwise.

OSM+IL-1 significantly reduced the protein concentration in a PKR-dependent manner. Thus, subsequent experiments focused on the mechanisms underlying this combined effect of OSM and IL-1.

OSM+IL-1 treatment increased cell death, however the mean cell number at the end of 7-days of culture was also slightly increased suggesting an increase in chondrocyte proliferation. OSM treatment of foetal liver cells stimulates cellular proliferation (Ehashi et al., 2005) but there have been no studies, to our knowledge, investigating the role of PKR in this process. Inhibition of PKR increased basal cell proliferation as well as further increasing proliferation of OSM+IL-1 treated cells. This is in keeping with the known role of PKR as a suppressor of cell growth (Koromilas et al., 1992). Mammalian cells normally have a low level of active PKR, which phosphorylates a small fraction of eIF $2 \alpha$, enough to hold the synthesis of cell growth promoting proteins in check but not to inhibit overall protein synthesis (Kim et al., 2000).

Our data, showing that OSM+IL-1 potently induced the expression of MMP9 mRNA supports the work of others (Milner et al., 2006; Blain et al., 2010). Extending these findings, our current study has shown that OSM+IL-1 treatment of articular chondrocytes additionally results in an increase in the activation of proMMP9, a key factor that contributes to joint destruction and inflammation in the arthritic joint. Our finding that OSM+IL-1 induced MMP9 mRNA is opposite to the findings of Koshy et al. (Koshy et al., 2002). The reason for this discrepancy may be due to the use of a cell line by Koshy et al. rather than primary chondrocytes here. Importantly, our observation that the PKR inhibitor significantly reduces OSM+IL-1 induced MMP9 mRNA and protein expression, as well as its activation, implicates PKR, for the first time, in the regulation of this cytokine-induced catabolic pathway. Our previous data using 2-aminopurine as an inhibitor of PKR found that activation of the PKR signalling pathway was critical in TNF $\alpha$ induced MMP9 expression and activation (Gilbert et al., 2004). This was supported by the studies of Takada et al. who demonstrated that TNF-induced MMP9 expression was abolished in PKR -/- cells (Radtke et al., 2002). Taken together, these data demonstrate that the PKR pathway is pivotal in mediating the pro-inflammatory cytokine-induced MMP9 synthesis and activation pathways known to be critical in arthritic cartilage degeneration.

Our finding that OSM+IL-1 increased both ADAMTS4 and $5 \mathrm{mRNA}$ expression is consistent with previous studies using bovine cartilage explants (Milner et al., 2006; Blain et al., 2010; Durigova et al., 2011) and human primary chondrocytes (Young et al., 2005). In addition, Koshy et al. (Koshy et al., 2002) reported that OSM+IL-1 induced ADAMTS4 but not ADAMTS5 in T/C28a4 cells (Koshy et al., 2002). Our data show that although ADAMTS5 was more highly expressed than ADAMTS4, the OSM+IL-1induced increases were far greater for ADAMTS4 gene expression compared to ADAMTS5 (830-fold vs. 40fold). These data, in conjunction with previous findings (Koshy et al., 2002; Durigova et al., 2011), suggest that ADAMTS4 is the primary aggrecanase responsible for the synergistic action of OSM+IL-1 on aggrecan degradation. We have shown for the first time that OSM+IL-1 induced up-regulation of ADAMTS4 and ADAMTS5 is, in part, mediated through PKR. Since the inhibition of PKR only 
partly decreased the level of ADAMTS4 and ADAMTS5 mRNAs, an additional signalling mechanism must be activated following OSM+IL-1 treatment and is likely to occur via a complex interplay of signal transduction pathways including the MAPK/ERK, PI3K/Akt, Jak/STAT, JNK1/2 and p38 kinase pathways (Blanchard et al., 2001; Catterall et al., 2001; Radtke et al., 2002; Barksby et al., 2006; El Mabrouk et al., 2007).

This is the first report, to our knowledge, that OSM+IL-1 treatment of bovine articular chondrocytes also decreases the expression of cartilage matrix genes (COL2A1, COL9A1, COL11A1 and ACAN). OSM+IL-1 thus profoundly alter chondrocyte homeostasis by decreasing matrix synthesis in conjunction with increasing matrix catabolism. OSM+IL-1 treatment resulted in a complete loss of type II collagen protein, consistent with the transcriptional down regulation we report as well as other studies showing that OSM+IL-1 induces collagenolysis (Milner et al., 2006; Litherland et al., 2008; Lakey and Cawston, 2009). A PKR independent mechanism for type II collagen breakdown is implicated since it was not prevented by PKR inhibition. Somewhat surprisingly, the effect of OSM+IL-1 on down-regulating the transcription of type II (COL2A1) and XI collagen $(C O L 11 A 1)$ and aggrecan $(A C A N)$ was enhanced when PKR was inhibited. One explanation is that OSM+IL-1 treatment increases the amount of active PKR within the cell to a level that is high enough to block the translation of proteins involved in the transcriptional control of these specific genes. Thus removing active PKR allows the translation of these OSM+IL-1 induced proteins to occur which then increases the negative effect on transcription of COL2A1,COL11A1 and ACAN although this remains to be confirmed. The precise mechanism of action at work here clearly requires further study. Inhibition of PKR did not significantly influence the effect of OSM+IL-1 on the expression of COL11A1 mRNA indicating that the OSM+IL-1 mediated down-regulation of the transcription of this gene maybe independent of the PKR signalling pathway.

Several studies have shown that treatment of chondrocytes with OSM+IL-1 increases the expression of MMP13, which plays a pivotal role, along with MMP1, in the breakdown of type II collagen and is thus likely to contribute to the loss of type II collagen shown here. MMP13 mRNA expression was also increased by OSM+IL-1 treatment in our study and this, indeed occurred through a mechanism that was independent of PKR. It is clear that a complex array of signalling interactions influence type II collagen breakdown following OSM treatment. These include ERK/MAPK mediated induction of ADAMTS4 and MMP13 (El Mabrouk et al., 2007), PI3K/Akt mediated induction of MMP1 and 13 (Yoshihara et al., 2000b) and the JAK/STAT, ERK1/2, JNK1/2, and p38 kinase pathways (Blanchard et al., 2001; Catterall et al., 2001; Radtke et al., 2002; Barksby et al., 2006). The nature of the cross-talk between PKR and these other signalling pathways remains to be elucidated.

Finally, our data reveal that OSM+IL-1 treatment of bovine articular chondrocytes results in a 10-fold increase in the expression of $T N F \alpha$ mRNA, which importantly, is partly mediated by PKR. This demonstrates that OSM+IL-1 propagate the inflammatory response in chondrocytes via activation of the PKR signalling pathway and induction of the pro-inflammatory cytokine, TNF $\alpha$. The OSM+IL-1 induced, PKR mediated upregulation of TNF $\alpha$ may occur via NFKB transcriptional activation (Kumar et al., 1994) or by direct binding of activated PKR to a cis-acting element in the $T N F \alpha$ pre-mRNA resulting in an increase in $T N F \alpha$ splicing and production in the cell (Osman et al., 1999; Kaempfer, 2003). PKR may also influence the OSM+IL-1 induced increases in expression of enzymes such as ADAM10 (Koshy et al., 2002) or MMP12 (own unpublished data) (Barksby et al., 2006; Milner et al., 2006) which process proTNF to its active form (Rosendahl et al., 1997; Matsumoto et al., 1998). An important question that remains to be elucidated is which of the PKR mediated effects of OSM+IL-1 treatment we have observed in the current study are via PKR's transcriptional effects on TNF $\alpha$.

\section{Conclusions}

In summary, we have clearly demonstrated for the first time that combined OSM and IL-1 treatment increased MMP9 expression and activation and ADAMTS4, ADAMTS5 and $T N F \alpha$ mRNA expression through a PKR dependant mechanism. Since these catabolic and pro-inflammatory effects are increased in human arthritis (Sandy et al., 1992; Yoshihara et al., 2000a), where TNF $\alpha$ helps drives cartilage degradation (Feldmann and Maini, 1999), these new roles for PKR are important. Targeting this PKR pathway may therefore have the potential to suppress MMP and ADAMTS expression during the inflammatory phase of cartilage destruction and thus presents a potential target for pharmaceutical intervention in arthritic disease.

\section{Acknowledgements}

This work was funded by Arthritis Research UK (grant numbers: 18221, 16436, and 18461). The authors thank Dr Peter Watson for the antibody to GM130, Dr Ilyas Khan for the provision of the $S O X 9$ and ADAMTS5 primers, Dr Siyuan Li for the ADAMTS4 primers, and the late Dr Ann Vaughan-Thomas for the COL9A1 and COL11A1 primers.

\section{References}

Barksby HE, Hui W, Wappler I, Peters HH, Milner JM, Richards CD, Cawston TE, Rowan AD (2006) Interleukin-1 in combination with oncostatin $\mathrm{M}$ upregulates multiple genes in chondrocytes: implications for cartilage destruction and repair. Arthritis Rheum 54: 540-550.

Besse S, Rebouillat D, Marie I, Puvion-Dutilleul F, Hovanessian AG (1998) Ultrastructural localization of interferon-inducible double-stranded RNA-activated enzymes in human cells. Exp Cell Res 239: 379-392. 
Blain EJ, Gilbert SJ, Hayes AJ, Duance VC (2006) Disassembly of the vimentin cytoskeleton disrupts articular cartilage chondrocyte homeostasis. Matrix Biol 25: 398408.

Blain EJ, Ali AY, Duance VC (2010) Boswellia frereana (frankincense) suppresses cytokine-induced matrix metalloproteinase expression and production of proinflammatory molecules in articular cartilage. Phytother Res 24: 905-912.

Blalock WL, Grimaldi C, Fala F, Follo M, Horn S, Basecke J, Martinelli G, Cocco L, Martelli AM (2009) PKR activity is required for acute leukemic cell maintenance and growth: a role for PKR-mediated phosphatase activity to regulate GSK-3 phosphorylation. J Cell Physiol 221: 232-241.

Blanchard F, Wang Y, Kinzie E, Duplomb L, Godard A, Baumann H (2001) Oncostatin M regulates the synthesis and turnover of gp130, leukemia inhibitory factor receptor alpha, and oncostatin $\mathrm{M}$ receptor beta by distinct mechanisms. J Biol Chem 276: 47038-47045.

Catterall JB, Carrere S, Koshy PJ, Degnan BA, Shingleton WD, Brinckerhoff CE, Rutter J, Cawston TE, Rowan AD (2001) Synergistic induction of matrix metalloproteinase 1 by interleukin-1alpha and oncostatin $\mathrm{M}$ in human chondrocytes involves signal transducer and activator of transcription and activator protein 1 transcription factors via a novel mechanism. Arthritis Rheum 44: 2296-2310.

Cawston TE, Ellis AJ, Humm G, Lean E, Ward D, Curry V (1995) Interleukin-1 and oncostatin M in combination promote the release of collagen fragments from bovine nasal cartilage in culture. Biochem Biophys Res Commun 215: $377-385$.

Cawston TE, Curry VA, Summers CA, Clark IM, Riley GP, Life PF, Spaull JR, Goldring MB, Koshy PJ, Rowan AD, Shingleton WD (1998) The role of oncostatin M in animal and human connective tissue collagen turnover and its localization within the rheumatoid joint. Arthritis Rheum 41: 1760-1771.

Chiu S-C, Yang N-S (2007) Inhibition of tumor necrosis factor-\{alpha\} through selective blockade of pre-mRNA splicing by shikonin. Mol Pharmacol 71: 1640-1645.

Clemens MJ, Bushell M, Jeffrey IW, Pain VM, Morley SJ (2000) Translation initiation factor modifications and the regulation of protein synthesis in apoptotic cells. Cell Death Differ 7: 603-615.

Clemens MJ, Elia A (1997) The double-stranded RNAdependent protein kinase PKR: structure and function. J Interferon Cytokine Res 17: 503-524.

Durigova M, Soucy P, Fushimi K, Nagase H, Mort JS, Roughley PJ (2008) Characterization of an ADAMTS-5mediated cleavage site in aggrecan in OSM-stimulated bovine cartilage. Osteoarthritis Cartilage 16: 1245-1252.

Durigova M, Troeberg L, Nagase H, Roughley PJ, Mort JS (2011) Involvement of ADAMTS5 and hyaluronidase in aggrecan degradation and release from OSM-stimulated cartilage. Eur Cell Mater 21: 31-45.

Ehashi T, Miyoshi H, Ohshima N (2005) Oncostatin M stimulates proliferation and functions of mouse fetal liver cells in three-dimensional cultures. J Cell Physiol 202: 698-706.
El Mabrouk M, Sylvester J, Zafarullah M (2007) Signaling pathways implicated in oncostatin M-induced aggrecanase- 1 and matrix metalloproteinase- 13 expression in human articular chondrocytes. Biochim Biophys Acta 1773: 309-320.

Fearon U, Mullan R, Markham T, Connolly M, Sullivan S, Poole AR, FitzGerald O, Bresnihan B, Veale DJ (2006) Oncostatin M induces angiogenesis and cartilage degradation in rheumatoid arthritis synovial tissue and human cartilage cocultures. Arthritis Rheum 54: 31523162 .

Feldmann M, Maini RN (1999) The role of cytokines in the pathogenesis of rheumatoid arthritis. Rheumatology (Oxford) 38 Suppl 2: 3-7.

Frye SR, Yee A, Eskin SG, Guerra R, Cong X, McIntire LV (2005) cDNA microarray analysis of endothelial cells subjected to cyclic mechanical strain: importance of motion control. Physiol. Genomics 21: 124-130.

Gilbert SJ, Duance VC, Mason DJ (2002) Tumour necrosis factor alpha up-regulates protein kinase $\mathrm{R}$ (PKR)activating protein (PACT) and increases phosphorylation of PKR and eukaryotic initiation factor 2-alpha in articular chondrocytes. Biochem Soc Trans 30: 886-889.

Gilbert SJ, Duance VC, Mason DJ (2004) Does protein kinase $\mathrm{R}$ mediate TNF-alpha- and ceramideinduced increases in expression and activation of matrix metalloproteinases in articular cartilage by a novel mechanism? Arthritis Res Ther 6: R46-R55.

Gilbert SJ, Blain EJ, Jones P, Duance VC, Mason DJ (2006a) Exogenous sphingomyelinase increases collagen and sulphated glycosaminoglycan production by primary articular chondrocytes: an in vitro study. Arthritis Res Ther 8: R89.

Gilbert SJ, Duance VC, Mason D (2006b) Protein kinase R: a novel mediator of articular cartilage degradation in arthritis. Curr Rheumatol Rev 2: 9-21.

Gilbert SJ, Blain EJ, Duance VC, Mason DJ (2008) Sphingomyelinase decreases type II collagen expression in bovine articular cartilage chondrocytes via the ERK signaling pathway. Arthritis Rheum 58: 209-220.

Hui W, Barksby HE, Young DA, Cawston TE, McKie $\mathrm{N}$, Rowan AD (2005) Oncostatin M in combination with tumour necrosis factor $\{$ alpha\} induces a chondrocyte membrane associated aggrecanase that is distinct from ADAMTS aggrecanase-1 or -2. Ann Rheum Dis 64: 16241632.

Hui W, Rowan AD, Richards CD, Cawston TE (2003) Oncostatin M in combination with tumor necrosis factor alpha induces cartilage damage and matrix metalloproteinase expression in vitro and in vivo. Arthritis Rheum 48: 3404-3418.

Jammi NV, Whitby LR, Beal PA (2003) Small molecule inhibitors of the RNA-dependent protein kinase. Biochem Biophys Res Commun 308: 50-57.

Jeffrey IW, Kadereit S, Meurs EF, Metzger T, Bachmann M, Schwemmle M, Hovanessian AG, Clemens MJ (1995) Nuclear localization of the interferon-inducible protein kinase PKR in human cells and transfected mouse cells. Exp Cell Res 218: 17-27.

Jimenez-Garcia LF, Green SR, Mathews MB, Spector DL (1993) Organization of the double-stranded RNA- 
activated protein kinase DAI and virus-associated VA RNAI in adenovirus-2-infected HeLa cells. J Cell Sci 106: 11-22.

Kaempfer R (2003) RNA sensors: novel regulators of gene expression. EMBO Rep 4: 1043-1047.

Kim SH, Forman AP, Mathews MB, Gunnery S (2000) Human breast cancer cells contain elevated levels and activity of the protein kinase, PKR. Oncogene 19: 3086 3094.

Koromilas AE, Roy S, Barber GN, Katze MG, Sonenberg N (1992) Malignant transformation by a mutant of the IFN-inducible dsRNA-dependent protein kinase. Science 257: 1685-1689.

Koshy PJ, Lundy CJ, Rowan AD, Porter S, Edwards DR, Hogan A, Clark IM, Cawston TE (2002) The modulation of matrix metalloproteinase and ADAM gene expression in human chondrocytes by interleukin-1 and oncostatin M: a time-course study using real-time quantitative reverse transcription-polymerase chain reaction. Arthritis Rheum 46: 961-967.

Kumar A, Haque J, Lacoste J, Hiscott J, Williams BR (1994) Double-stranded RNA-dependent protein kinase activates transcription factor NF-kappa B by phosphorylating I kappa B. Proc Natl Acad Sci USA 91: 6288-6292.

Lakey RL, Cawston TE (2009) Sulfasalazine blocks the release of proteoglycan and collagen from cytokine stimulated cartilage and down-regulates metalloproteinases. Rheumatology (Oxford) 48: 1208-1212.

Langdon C, Kerr C, Hassen M, Hara T, Arsenault AL, Richards CD (2000) Murine oncostatin M stimulates mouse synovial fibroblasts in vitro and induces inflammation and destruction in mouse joints in vivo. Am J Pathol 157: 1187 1196.

Lee SB, Esteban M (1994) The interferon-induced double-stranded RNA-activated protein kinase induces apoptosis. Virology 199: 491-496.

Litherland GJ, Dixon C, Lakey RL, Robson T, Jones D, Young DA, Cawston TE, Rowan AD (2008) Synergistic collagenase expression and cartilage collagenolysis are phosphatidylinositol 3-kinase/Akt signaling-dependent. J Biol Chem 283: 14221-14229.

Little CB, Barai A, Burkhardt D, Smith SM, Fosang AJ, Werb Z, Shah M, Thompson EW (2009) Matrix metalloproteinase 13-deficient mice are resistant to osteoarthritic cartilage erosion but not chondrocyte hypertrophy or osteophyte development. Arthritis Rheum 60: 3723-3733.

MacQuillan G, Caterina P, de Boer B, Allan J, Platten M, Reed W, Jeffrey G (2009) Ultra-structural localisation of hepatocellular PKR protein using immuno-gold labelling in chronic hepatitis $\mathrm{C}$ virus disease. J Mol Histol 40: 171176.

Matsumoto S, Kobayashi T, Katoh M, Saito S, Ikeda Y, Kobori M, Masuho Y, Watanabe T (1998) Expression and localization of matrix metalloproteinase-12 in the aorta of cholesterol-fed rabbits: relationship to lesion development. Am J Pathol 153: 109-119.

Milner JM, Rowan AD, Cawston TE, Young DA (2006) Metalloproteinase and inhibitor expression profiling of resorbing cartilage reveals pro-collagenase activation as a critical step for collagenolysis. Arthritis Res Ther 8: R142.

Osman F, Jarrous N, Ben-Asouli Y, Kaempfer R (1999) A cis-acting element in the 3'-untranslated region of human TNF-alpha mRNA renders splicing dependent on the activation of protein kinase PKR. Genes Dev 13: 3280-3293.

Patel CV, Handy I, Goldsmith T, Patel RC (2000) PACT, a stress-modulated cellular activator of interferon-induced double-stranded RNA-activated protein kinase, PKR. J Biol Chem 275: 37993-37998.

Radtke S, Hermanns HM, Haan C, Schmitz-Van De Leur H, Gascan H, Heinrich PC, Behrmann I (2002) Novel role of Janus kinase 1 in the regulation of oncostatin $M$ receptor surface expression. J Biol Chem 277: $11297-$ 11305

Rosendahl MS, Ko SC, Long DL, Brewer MT, Rosenzweig B, Hedl E, Anderson L, Pyle SM, Moreland J, Meyers MA, Kohno T, Lyons D, Lichenstein HS (1997) Identification and characterization of a pro-tumor necrosis factor-alpha-processing enzyme from the ADAM family of zinc metalloproteases. J Biol Chem 272: 24588-24593.

Sandy JD, Flannery CR, Neame PJ, Lohmander LS (1992) The structure of aggrecan fragments in human synovial fluid. Evidence for the involvement in osteoarthritis of a novel proteinase which cleaves the Glu 373-Ala 374 bond of the interglobular domain. J Clin Invest 89: $1512-1516$.

Scheuner D, Patel R, Wang F, Lee K, Kumar K, Wu J, Nilsson A, Karin M, Kaufman RJ (2006) Double-stranded RNA-dependent protein kinase phosphorylation of the alpha-subunit of eukaryotic translation initiation factor 2 mediates apoptosis. J Biol Chem 281: 21458-21468.

Takaishi H, Kimura T, Dalal S, Okada Y, D'Armiento J (2008) Joint diseases and matrix metalloproteinases: a role for MMP-13. Curr Pharm Biotechnol 9: 47-54.

Tam CL, Hofbauer M, Towle CA (2007) Requirement for protein kinase $\mathrm{R}$ in interleukin-1alpha-stimulated effects in cartilage. Biochem Pharmacol 74: 1636-1641.

Taylor S, Wakem M, Dijkman G, Alsarraj M, Nguyen M (2010) A practical approach to RT-qPCR-Publishing data that conform to the MIQE guidelines. Methods 50: S1-5.

van den Berg WB (2011) Osteoarthritis year 2010 in review: pathomechanisms. Osteoarthritis Cartilage 19: 338-341.

Vaughan-Thomas A, Dudhia J, Bayliss MT, Kadler KE, Duance VC (2008) Modification of the composition of articular cartilage collagen fibrils with increasing age. Connect Tissue Res 49: 374-382.

Vaughan-Thomas A, Gilbert SJ, Duance VC (2000) Elevated levels of proteolytic enzymes in the aging human vitreous. Invest Ophthalmol Vis Sci 41: 3299-3304.

Yoshihara Y, Nakamura H, Obata K, Yamada H, Hayakawa T, Fujikawa K, Okada Y (2000a) Matrix metalloproteinases and tissue inhibitors of metalloproteinases in synovial fluids from patients with rheumatoid arthritis or osteoarthritis. Ann Rheum Dis 59: 455-461.

Yoshihara Y, Nakamura H, Obata Ki, Yamada H, Hayakawa T, Fujikawa K, Okada Y (2000b) 
Matrix metalloproteinases and tissue inhibitors of metalloproteinases in synovial fluids from patients with rheumatoid arthritis or osteoarthritis. Ann Rheum Dis 59: 455-461.

Young DA, Lakey RL, Pennington CJ, Jones D, Kevorkian L, Edwards DR, Cawston TE, Clark IM (2005) Histone deacetylase inhibitors modulate metalloproteinase gene expression in chondrocytes and block cartilage resorption. Arthritis Res Ther 7: R503-512.

Zhu S, Romano PR, Wek RC (1997) Ribosome targeting of PKR is mediated by two double-stranded RNA-binding domains and facilitates in vivo phosphorylation of eukaryotic initiation factor-2. J Biol Chem 272: $14434-$ 14441 . 